\title{
250. Yılında Kant'ın Duyulur ve Anlaşılır Dünyanın Form ve İlkeleri Eseri Üstüne
}

\section{On Kant's Form and Principles of the Sensible and the Intelligible World on its 250th Anniversary}

\author{
Özgüç Güven ${ }^{1}$ (1)
}

'Doç. Dr., İstanbul Üniversitesi, Edebiyat Fakültesi, Felsefe Bölümü, İstanbul, Türkiye

ORCID: Ö.G. 0000-0001-7223-0356

\section{Sorumlu yazar/Corresponding author: Özgüç Güven \\ İstanbul Üniversitesi, Edebiyat Fakültesi, Felsefe Bölümü, İstanbul, Türkiye \\ E-posta/E-mail: ozguc@istanbul.edu.tr \\ Başvuru/Submitted: 20.11. 2020 Kabul/Accepted: 11.12 .2020}

Atıf/Citation: Guven, Ozguc. (2020).“250. Yılında Kant'ın Duyulur ve Anlaşılır Dünyanın Form ve Illkeleri Eseri Üstüne" Felsefe ArkiviArchives of Philosophy, 53: 123-151. https://doi.org/10.26650/arcp.844123

\section{ÖZET}

Kant, 1770 yılında Duyulur ve Anlaşıır Dünyanın Form ve Illkeleri eserini kaleme aldıktan sonra on yıl boyunca sessiz kalıp ardından Saf Aklın Eleştirisi'ni yazar. Bu bakımdan 1770 tezi Kant'ın eleştirel döneme geçiş eseri olarak değerlendirilir. Eser Kant'ın bitmez uğraşı metafiziği sağlam bir eksene yerleştirmek için giriş önerisidir. Bu bağlamda Kant duyusallığın konusu olan dünya ile anlayışın konusu olan dünyayı ayırarak metafizik için bir yol arar. Duyusallığa konu edilen dünya uzay ve zaman formları yoluyla kavranabilir. Anlaşılır dünya ise duyuların sızıntılarından uzak yalnızca anlayış kavramları yoluyla belirlendiğinde metafizik yanılsamalardan korunabilir. 1770 tezi, Saf Aklın Eleştirisi'nin özellikle transendental estetik bölümü göz önünde bulundurulduğunda eleştirel dönemle büyük oranda örtüşse de anlaşlır dünyada noumenanın bilinebileceğini varsayması açısından eleştirel dönemden uzaklaşır. Çalışmada 1770 tezinin temel varsayımlarını ortaya koyarak bu varsayımları eleştirel dönemle ilgileri açısından ele alacağız. Özellikle, Saf Aklın Eleştirisi'nin A ve B baskılarında iki kez yazılan, deneyim ile anlama yetisi kavramları arasındaki uyuşmayı ele alan transendental türetim sorununun başlangıcının 1770 tezinde olduğunu göstereceğiz. Böylelikle 1770 tezinin eleştirel felsefede sürdürülen ve yadsınan varsayımlarını belirgin kılacağız. Çalışmadaki bir başka çabamız ise 1770 'ten sonraki mektuplaşmaları yoluyla Kant'ın felsefi tutumunun nasıl farklılaştığını ortaya koymak olacak. 1772 yılında Herz'e yazdığı ünlü mektuptan önce Kant'ın Lambert, Herz ve Mendelssohn'la yazışmalarında yer alan 1770 tezi değerlendirmelerinin eleştirel döneme geçiş sürecini nasıl etkilediğini konu edeceğiz.

Anahtar Kelimeler: Kant'ın eleştiri öncesi felsefesi, Kant'ın eleştirel felsefesi, duyusallık, anlayış, 1770 Tezi

\section{ABSTRACT}

In 1770, Kant wrote On the Form and Principles of the Sensible and the Intelligible World and then remained silent for 10 years before the Critique of Pure Reason. In this respect, Dissertation is considered as Kant's transitional text to the critical period. It is a propaedeutic to posit placing metaphysics on a sound foundation by separating the world that is the subject to sensibility from the world that is the subject to understanding. While the sensible world is comprehended through forms of space 
and time, the intelligible world should be comprehended separately from the contamination of the senses in order to be protected from metaphysical illusions. Although the Dissertation converges with the critical period, particularly concerning the Critique's the transcendental aesthetic section of the Critique, it diverges from the critical period by arguing that the noumenon is known in the intelligible world. In this regard I will clarify the basic assumptions of the Dissertation and discuss their relevance to the critical period in my paper. In particular, I will show that the core of the transcendental deduction, which deals with the problem of agreement between experience and the concepts of understanding, rewritten twice in the A and B editions of the Critique, is in the Dissertation. Thus, I will clarify which assumptions of the Dissertation remained and which abandoned in critical philosophy. Another aim of my paper is to expose how Kant's correspondence with Lambert, Herz and Mendelssohn between 1770 and 1772 affected Kant's philosophical development toward the Critique.

Keywords: Kant's pre-critical philosophy, Kant's critical philosophy, Inaugural Dissertation, sensibility, intelligence

\section{Giriş}

Kant'ın Duyulur ve Anlaşllır Dünyanın Form ve İlkeleri Üstüne $e^{1}$ adlı eseri Königsberg Üniversitesinde ${ }^{2}$ uzun süreden beri beklediği profesörlük kadrosunu alabilmek için yaptığı çalışmadır. Daha önce Latin şiir sanatı kürsüsü için yapılanın yanı sıra, 1769'da Jena ve 1770 'te Erlangen Üniversitesi'nden gelen profesörlük tekliflerine karşın Kant Königsberg'de kalmayı seçmiştir. ${ }^{3}$ Kadro için başvuruyu mart ayında yapan Kant, 31 Mart'ta felsefe bölümünde mantık ve metafizik profesörlügüne hızlıca atanır. Henüz en önemli eserlerini vermemiş olsa bile o sıralar Prusyảnın önde gelen filozoflarından biri olarak görülür. Kural gereği kadroya atandıktan sonra tez sunması beklenildiğinden kısa sayılabilecek bir süre içinde çalışmasını tamamlayarak 21 Ağustos'ta tezi savunur. Üç kişilik jüri önünde gerçekleşen savunmada sözcüsü tıp öğrencisí Marcus Herz (1747-1803) olur.

1770 tezinin Kant'ın eleştirel felsefesi açısından durumu tartışma konusudur. Kendisi de dahil olmak üzere kimileri bu çalışmayı Kant'ın eleştirel dönemiyle yakından ilişkilendirir. Bu bağlamda Kant, Herz’e 1 Mayıs 1781 yılında yazdığı mektupta Saf Aklın Elesstirisi’nin duyulur dünya ve anlaşılır dünya başlı̆̆ alında tartıştığı kavramlardan başlayan çeşitli araşıırmaların sonuçlarını içerdiğini bildirir. ${ }^{5}$ Dahası 13 Ekim 1797'de Johann Heinrich Tieftrunk, kısa yazılarını derlemeyi teklif ettiğinde Kant tüm eserlerinin bu kitapta yer almasını istemez ve kitabın 1770 tezi ile başlamasını önerir. ${ }^{6} \mathrm{Ne}$ var ki, yaşamının son dönemlerinde Immanuel Kant's Vermischte

1 De Mundi Sensibilis atque Intelligibilis Forma et Principiis. Bundan sonra metin içinde 1770 tezi olarak geçecek.

2 Albertina Üniversitesi olarak da bilinir.

3 Manfred Kuehn, Kant: A Biography, çev. Bülent O. Doğan (İstanbul: Türkiye İş Bankası Kültür Yayınları, 2011) 179.

4 O dönemde Yahudiler yalnızca tıp fakültelerine kabul edilmektedirler. (Paul Guyer, Kant, s 382)

5 10:266. Immanuel Kant, "Briefwechsel 1747-1788", içinde Kant's gesammelte Schriften Preußische Akademie der Wissenschaften, c. X, 1911. [Kant’a tüm atıflar Almanca Königlichen Preußischen Akademie der Wissenschaften (ed.), 1900-, Kants gesammelte Schriften, Berlin: Georg Reimer edisyonu ile İngilizce P. Guyer and A. Wood (eds.), 1992-, The Cambridge Edition of the Works of Immanuel Kant, Cambridge: Cambridge University Press edisyonu karşılaştırılarak yapılacak. Immanuel Kant, Philosophical Correspondence 1759-1799, çev. Arnulf Zweig (Cambridge: Cambridge University Press, 1999] 
Schriften adıyla çıkan seçki kitapta 1770 'ten önceki eserleri de yer alır. ${ }^{7}$ Bununla birlikte çalışmayı Kant'ın en dogmatik çalışmalarından biri olarak ananlar da bulunur. ${ }^{8}$

1770 tezinin eleştirel dönemdeki yerini ortaya koyabilmek için Kant'ın tezden bir süre önce yürüttüğü felsefi tartışmaları konu ederek çalışmamıza başlayacağız. Ardından 1770 tezinin içeriğini serimleyeceğiz. Daha sonra Herz'in 1772'deki mektubuna kadar Kant'ın 17701772 yılları arasındaki yazışmalarını ele alarak 1770 tezinin hangi bakımlardan ve ne türden gerekçelerle eleştirildiğini ortaya koyacağız. Bu tartışmaları açarken yeri geldikçe 1770 tezindeki kimi kavramların eleştirel dönemde değişimini göstereceğiz.

\section{1770 Tezi Öncesi}

1770 tezi Kant'ın yaşamı boyunca kaleme aldığı dört Latince ${ }^{9}$ eserden sonuncusudur. Eser beş bölümden oluşur: (1) genel olarak dünya kavramı üstüne (2) genel olarak duyulur ile anlaşılır şeyler ayrımı üstüne (3) duyulur dünyanın formunun ilkeleri üstüne (4) anlaşılır dünyanın formunun ilkeleri üstüne (5) metafizikte anlayışsal ve duyusal olanla ilgilenen yöntem üstüne. Kant tezin yazılmasından kısa bir süre sonra 2 Eylül 1770'te Johann Heinrich Lambert'e (17281777) yazdığ mektupta $^{10}$ çalışmanın 1. ve 4. bölümlerinin üstünkörü okunabileceğini, ilginin asıl yöneltilmesi gereken bölümleri 2., 3., 5. olarak belirler. Önemsediği bölümlerde Kant, duyulur dünya ile anlaşılır dünya ayrımı yoluyla uzay ve zamanı duyusallığın formları olarak ortaya koyup metafiziksel yanılgılardan kaçınmayı sağlayacak metafiziksel yöntemi tartışır. Bu durum eserin hacmine de yansımıştır. Eserin yarısından daha fazlası duyulur dünyaya, çok az bölümü anlaşılır dünyaya, kalanı ise her birine ilişkin yöntemsel yaklaşıma ayrılmıştır. Dolayısıyla Kant’ın anlaşılır dünyaya yönelik yürüttüğü tartışmadan metni yazarken hoşnut olmadığını söyleyebiliriz. Duyulur dünyaya yönelik yaklaşımı ise onun 1768'de Uzaydaki Yönlerin Farklılı̆̆ının İlk Temeli Üstüne (Alm. Von dem ersten Grunde des Unterschiedes der Gegenden im Raume) adlı eserinde başladığı uzay tartışmasının zamanın da katılarak evriltilmesi olarak görülebilir.

7 Kant 1770 öncesi çalışmaları konusunda yıkıcı davranmaktadır. Eleştirel dönemin dağarcığı yoluyla bakıldığında bu dönemde Tanrı kanıtlamaları gibi sonradan dogmatik bulduğu tartışmalar olduğu görülse de özgün yaklaşımlar da bulunur. Bunlardan biri 1755 yılında yazdığı Evrensel Doğa Tarihi ve Gökler Kuraminda yer alan Güneş Sistemi’nin bir bulutsudan fiziksel kuvvetler yoluyla meydana geldiğini ileri sürdüğü, sonradan Kant-Laplace gaz kuramı olarak anılacak çalışmadır.

8 Aktaran Paulo R. Licht Santos, “The Real Use of the Understanding and Ontology in Kant's Inaugural Dissertation”, içinde Kant Und Die Philosophie in Weltbürgerlicher Absicht: Akten des Xi. Kant-Kongresses 2010, ed. Margit Ruffing vd. (De Gruyter, 2010), 648.

9 Bu eserler sırasıyla; 12 Haziran 1755 Ateş Üzerine (De İgne) teziyle Magister'lik unvanı kazanır. 27 Eylül 1755 Metafiziksel Bilginin İlk İlkelerinin Yeni Bir Açıklaması (Principiorum primorum cognitionis metaphysicae nova dilucidatio). Bu çalışma ile Kant üniversitede ders verme izni alır. 10 Nisan 1756 Geometriyle Birleştirilmiş; Metafiziğin Doğa Felsefesinde Kullanımı. I. Kısım: Fiziksel Monadoloji (Metaphysica cum geometria iunctae usus in philosophia naturalis, cuius specimen I. Continet monadologiam physicam). Profesörlük kadrosu için ön şart olarak yapılması gereken bir çalışma. Kant çok iyi Latince bilmesine karşın akademik kurallar gereği özellikle Latince yazılması istenen eserler dışındakileri Almanca kaleme alarak Almanca kavram dağarcığının oluşmasına büyük katkı sağlar.

10 Immanuel Kant, Philosophical Correspondence 1759-1799, çev. Arnulf Zweig (Cambridge: Cambridge University Press, 1999). 
1770 tezinden önce Kant'ın bir arayışın filozofu olduğunu söylemek yanlış olmayacaktır. Yaptığı çalışmalarda takındığı felsefi tutum yıldan yıla değişmektedir. 1760'ların başlarında Leibnizci-Wolffçu akılcı geleneğe ilgi duyarken, Hume’un Almancaya çevrilmesinden sonra İngiliz deneyci geleneğine yönelmiş olduğu görülür. $\mathrm{Ne}$ var ki, dönem dönem yoğunlaşan ilgileri bulunsa da Kant kendi olmanın da peşindedir. Bu çabası 9 Mayıs 1768 yılında Johann Gottfried Herder'e (1744-1803) yazdığı mektupta Kant’ın şu sözlerinde açı̆̆a çıkar: “Gerek başkalarının görüşlerine gerekse kendi görüşlerime yönelik derin bir kayıtsızlıkla sık sık yapıyı tümden altüst ediyorum ve farklı bakış açılarından tekrar ele alarak en sonunda sistemi doğru bir şekilde oluşturmayı umabileceğim konuma ulaşmaya çalışıyorum.” Bu bağlamda Kant'ın 1766'da Metafizik Düşlerle Aydınlatılan Bir Büyücünün Düşleri (Alm. Traume eines Geistersehers, erlautert durch Traume der Metaphysik) eserinde takındığı deneyci tavır dikkat çekicidir. Bu çalışma İsveçli felsefeci, bilim insanı, gizemci ve kâhin Swedenborg'a (1688-1772) karşı bir polemik metnidir. Swedenborg başlarda mucit ve bilim insanı olarak parıltılı çalışmalar yapıp dikkat çekse de sonraları gizemci yola girerek dinsel içerikli düşler gördüğünü öne sürmüştür. Bu düşlerde İsa’nın kendisine Hristiyanlığı düzeltme görevi verdiğini ortaya atarak, canı istediği zaman cennet ve cehennemi ziyaret edebileceğini, melekler, şeytanlar ve diğer tinsel varlıklarla

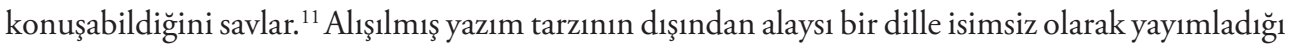
bu çalışmasında Kant'ın temel savlarından biri ruhların bilmenin konusu olamayacağıdır. Bu nedenle böylesi bir metafiziğe yıkıcı bir tepki göstermek için "metafiziğin tüm kavramlarıyla ve tüm metafiziksel tutumlarla, metafiziksel tanımlarla ve metafiziksel kesinliklerle, metafiziksel kategoriler ve bu kategorilerin elde edildiği mantıksal çıkarım zincirleriyle inceden inceye alay" eder. ${ }^{12}$ Söz konusu güçlü vurgudan dolayı bu çalışma Kant'ın felsefi gelişimi açısından deneyci aşama olarak görülür. ${ }^{13}$

1766-1768 arasında Kant, Lambert, Herder ve Moses Mendelssohn'la (1729-1786) mektuplaşmalarında metafiziğe yönelik ilgisini yer yer ortaya koysa da metafiziğin amacına ya da yöntemine ilişkin belirgin bir açıllama yapmaz. ${ }^{14}$

Uzaydaki Yönler'de Kant Leibnizci uzay anlayışını eleştirir. Daha önce Leibniz analysis situs ${ }^{15}$ anlayışı ile monadlar üzerinden uzayın temel özelliklerini konu etmiştir. Bu bağlamda uzayı ve zamanı, monadların bağıntılarından türetilmiş göreli birer kavram olarak ele alır. ${ }^{16}$ Çalışmada Kant’ın ana tartışması konum (Alm. Lagen) ile yönü (Alm. Gegend) ayırmaktır. Konum tek bir varolanın uzaydaki durumuyla, yön ise mutlak uzay içinde konumların birlikteliğiyle ilgilidir. ${ }^{17}$ Kant açısından mutlak uzay "tüm maddelerin varoluşundan bağımsızdır ve maddenin bileşik

11 Martin Schönfeld ve Michael Thompson, "Kant's Philosophical Development”, içinde The Stanford Encyclopedia of Philosophy, ed. Edward N. Zalta, 2019.

12 Ernst Cassirer, Kant’ın Yaşamı ve Öğretisi, çev. Doğan Özlem (İstanbul: İnkılâp Kitabevi, 1996) 89.

13 Paul Guyer, Kant (New York: Routledge, 2006) 25.

14 Frederick C Beiser, "Kant's Intellectual Development: 1746-1781", içinde The Cambridge Companion to Kant, ed. Paul Guyer (Cambridge: Cambridge University Press, 1992), 48.

15 Vincenzo De Risi, "Analysis Situs, the Foundations of Mathematics, and a Geometry of Space”, içinde The Oxford Handbook of Leibniz, ed. Maria Rosa Antognazza (New York: Oxford university press., 2018) 248.

16 Bertrand Russell, The Philosophy of Leibniz (London: Routledge, 1997) 225.

$17 \quad 2: 377$. 
niteliğinin olanağının sonuncu temeli olarak kendi gerçekliğini [Alm. Realität] taşır”18. Bunun yanı sıra uzay, tüm dışsal duyumu olanaklı kılan temel kavramdır. ${ }^{19}$ Kant’a göre yönlülük kavrayışımız bedenlerimiz ile düzlem arasındaki bağıntılardan türetilmiştir. Düzlemdeki nesnenin konumu ile bedenimiz arasındaki bağıntı yönü saptar. Ne var ki, bu yönün anlaşılır olması hem düzlemi hem de nesneyi içine alan bir uzayın bulunuşu ile anlaşılabilir. Kant'ın varsayımının temel gerekçesi örtüşemezliktir. ${ }^{20}$ Öyle ki, üç-boyutlu nesneler düşünüldüğünde, sözgelimi küresel üçgenler ya da eldiven çiftleri, bütün içsel özellikleri bakımından aynı olan bu eş parçalar birbirlerinin yerine geçemez. Bunun nedeni parçalardan birini çevreleyen yüzeyin diğerini çevreleyememesidir. Dolayısıyla Kant’a göre özellikle Alman filozofların uzayı madde parçalarının dışsal bağıntısından oluşturması yanlışıır. ${ }^{21}$ Uzayın belirlenimleri birbirlerine göre madde parçalarının konumlarının sonuçları değildir. Konum uzaya göre belirlenir. Böylece "mutlak ve kökensel (Alm. ursprünglichen) uzayın bir sonucu olarak fiziksel şeyler arasındaki bağıntı olanaklıdır." 22 Bu noktada Allison'a göre Kant'ın bu sıralardaki ilgisi uzaya ilişkin ontolojik bir çıkarım yapmaktansa deneysel ve matematiksel bakımdan uzayı konu etmeye dönüktür. ${ }^{23} \mathrm{Ne}$ var ki, Kant henüz, uzayın duyarlığın öznel formu olduğu düşüncesine ulaşmış değildir. Öte yandan uzayın bilinişiyle ilgili kuşkuları bulunur: "Bu incelemedeki amacım, uzanım hakkında görüsel yargıların bulunup bulunmadığını görmektir”24 diyerek arayışını dile getirir.

Beck'e göre Uzaydaki Yönler’in ardından Kant'a 1768 yılında profesörlük kadrosu önerilseydi ve Kant bu tarihte bir sunuş tezi yazsaydı 1770'tekinden bambaşka yazard.. ${ }^{25}$ Beck, 1768'de bir tez yazılmış olsaydı Kant'ın şu görüşleri dile getireceğini öne sürer: Deneyim dışındaki şeyleri ve tözlere ilişkin yetileri bilmeye yönelik kurgusal bir metafiziği yadsırdı, metafiziğin görevi bilginin sınırlarını ve temellerini belirlemek olurdu ve metafiziğin yöntemi doğa bilimlerinki gibi olurdu, deneyimin çözümlenişi sonrasında bazı çözümlenemez kavramlar ve kanıtlanamaz önermeler bulunurdu, metafizik insanlığın hakiki ve sürüp giden iyiliğinden ayırt edilemez biçimde anlaşılırdı, uzay Eukleidesçi ve Newtoncu olurdu, uzay deneyim yoluyla duyusal olarak bilinmezdi bunun yerine aklın bir düşüncesi yolu ile içsel duyuların görüsü ya da temel bir kavram olarak bilinirdi, matematiğin yöntemi felsefenin yönteminden tümüyle farklı olurdu, uzayda gözlemlenen şeyler nedensel yasalarca belirlenirdi. ${ }^{26}$

1770 tezinden önce Kant 1770 yılını anarken şöyle demektedir: "1769 yılı bana sonu gelmez büyük bir ışık yaktı”27. Uzaydaki Yönler'den sonra 1769'un “büyük sşı̆̆ıyla” Kant doğa bilimleri ile metafizik arasında bir süreklilik bulunmadığını, ikisinin bilgideki ayrı parçalar olduğunu savlar.

$18 \quad 2: 378$.

$192: 383$.

20 Bu tartışma için bkz. H. Bülent Gözkân, Kant’ın Şemsiyesi (İstanbul: YKY, 2018).

$212: 383$.

22 2:283.

23 Henry E. Allison, Kant's Transcendental Deduction An Analytical-Historical Commentary (Oxford: Oxford University Press, 2015) 46.

$242: 378$.

25 Lewis White Beck, Essay on Kant and Hume (New Haven: Yale University Press, 1978) 101.

26 Beck, 101-102.

27 18:69. 
Beck bu değişimi Kant'ın Platon'la ve Leibniz'in Nouceaux Essaisizle olan ilgisine bağlar. ${ }^{28} 1770$ tezi deneyim ile metafizik arasında sürekliliği yadsıyarak Platon ve Leibnizci bir çizgide durur. Ayrıca 1769 yılında yanan "büyük ışık” yetiler arasında ayrıma yönelik de olmalıdır. 1770’le birlikte duyular ile düşünme yetisi ayrımı yapılarak, duyuları düşüncenin aşağı, silik belirsiz yanı olarak görme tavrı ortadan kalkar. Beck'in üzerinde durduğu bir başka yan içerik ve form ayrımı hakkındadır. ${ }^{29}$ İçerik ve form, duyulur ve anlaşılır olanın her ikisinde de yer alır. Beck, böylece Kant’ın Baumgartencı duyusal bilginin bilimi olarak estetikten söz edebilme olanağına ulaştığını vurgular. Artık duyusallık bilgi açısından yalnızca içerik değil biçim de sağlamaktadır.

1770 tezinin Latince kaleme alınmış olması ve Kant'ın eleştirel felsefesi açısından bir geçiş çalışması olması, kimi kavramların gönderimleri bakımından güçlükler sunmaktır. Öyle ki, Latince eserin Almanca çevrilerinde bile bu ayrımlar ${ }^{30}$ görünür. Söz konusu güçlüklerin nedeni eleştirel dönemde kavram gönderimlerinin değişmesidir. Bu kavramların öne çıkan ikisi idea ve intellectustur. Eleştirel dönemde yer alan Almanca idee, aklın özelleşmiş bir kullanımı olarak ele alınırken 1770 tezinde düşünce içeriği olma bağlamında yer bulmuştur. Şema da aynı biçimde eleştirel dönemde olduğu gibi, bir sentez kuralını anmak için kullanılmaz. Bir diğer kavram tezin başlığında da yer bulan intelligibilistir. Intelligibilis için düşünülür demek yerine anlaşılır kullanmayı öneriyorum. Bu seçimi şu gerekçelere dayandırıyorum. Kant’ın eleştirel dönem öncesi eserlerinin Cambridge edisyonunda bulunan Almanca-İngilizce sözlüğe düşülen notlarda Kant'ın döneminde Latince intellectus karşılığı olarak Almancada Verstand kullanıldığı bildirilir. ${ }^{31}$ Şimdilerde Almancada Intellekt yer almasına karşın Kant’ın zamanında kullanılmamaktadır. Öyle ki, Intellekt ne Grimm ne de Campe'nin Almanca sözlüklerinde yer alır. Kant, Intellectus kullanırken, Verstand'ı göz önüne getiriyor görünmektedir. İngilizce çevirilerde yer yer intellectual geçmesi ise understanding'den sıfat türetilememesi ile ilişkilendirilmektedir. Bütün bunlardan ötürü çalışmada intellectus yerine "anlayış" akıl [Alm. Vernunft] ile anlama yetisi [Alm. Verstand] arasında ayrım göz önünde tutulduğunda Kant'ın Verstand'in gönderimini zamanla değiştirdiği görülür. 1770 tezinde Kant aklın intellectus ile şeylerin kendiliklerine uzanan bir alanı kavrama savındayken eleştirel dönemde bundan vazgeçer. Bundan ötürü 1770'teki Verstand anlayışı ile 1781'deki farklıdır. Bu farkı korumak için ilkine karşılık anlayış ikincisine anlama yetisi kullanmayı öneriyorum.

28 Beck, 103.

29 Beck, 104.

30 Söz konusu ayrımlar eserin başlığının çevrisinde bile görülür. Almanca çeviriler şöyledir:

J. H. Tieftrunk, Von der Form und den Prinzipien der Sinnen und Verstandeswelt,

J. H. von Kirchmann, Über die Form und die Prinzipien der Sinnlichen und der Verstandeswelt

K. Vorlander, Über die Form und die Prinzipien der Sinnen und der Verstandeswelt

K. Reich, Über die Form und die Prinzipien der Sinnen und Geisteswelt

N. Hinske, Von der Form der Sinnen- und Verstandeswelt und Ihren Grunden

31 Bkz. Immanuel Kant, "On the Form and Principles of the Sensible and the Intelligible World [Inaugural Dissertation]”, içinde Theoretical Philosophy, 1755-1770, çev. David Walford ve Ralf Meerbote (New York: Cambridge University Press, 1992), 489. dipnot. 


\section{Dünya Kavramı Üstüne}

Kant, tezine dünyayı irdeleme nesnesi yaparak başlar. Öyle ki, dünyanın yapısının ortaya konulması metafiziğin olanağının tartışılmasını sağlar. Kant, bu olanağı soruştururken "zihnin [Lt. mentis] doğasından” açığa çıkartabileceklerimizin metafiziğin yöntemine ilişkin kavrayışımızı derinleştirebileceğini öne sürmektedir. ${ }^{32}$ Dünya kendisi parça olmayan bütündür [Lt. totum, İng. whole]. Buna karşılık gelen basit ise kendisi bütün olmayan parçadır. Böylece dünya kavramının duyusallık ve anlayı̧ yetileri aracıllğıyla çözümlenmesi ve bileşimi yoluyla ikili oluşumu metafizik için araştırma bağlamı sunar. Kant açısından söz konusu araştırma bütün ile bileşenleri arasındaki bağıntının iki farklı biçimde; parçadan bütüne, bütünden parçaya olmak üzere ortaya konulabileceğini gösterir. Burada bir yandan anlayıs [Lt. intellectus] ile parçalar bütüne ulaştırılır öte yandan bilginin duyusal yetisi yoluyla [Lt. facultatem cognoscendi sensitivam] ve seçik bir görü [intuitus distincto] yoluyla kavram tasarlanabilir. ${ }^{33}$ Anlayış bütünü konu edişini tümel ideleri [Lt. ideas intellectus et universales] yoluyla yapar.

Kant açısından bir bileşik [Lt. compositionis, İng. compound] için parçaların çokluğu [Lt. multitudo, İng. multiplicity]; bütün için parçaların toplamı [Lt. omnitudo İng. totality] gereklidir. ${ }^{34}$ Basit olanın kavramı ancak çözümleme yoluyla, bütün olanın kavramı ancak bileşim aracılığıyla meydana gelir. Bu işlemler sonlu ve belirli bir zamanda yürütülür. ${ }^{35}$ Öte yandan sürekli büyüklük [Lt. quanto continuo, İng. continous magnitude] durumunda bütünden parçalara gerileme ve sonsuz büyüklük [İng. infinite magnitude] durumunda parçadan bütüne ilerlemenin limiti [Alm. termino] bulunmaz. Bu durumda tam bir çözümleme ve bileşim olanaksızdır. Sürekli büyüklük, görü yasaları [Lt. leges intuitus] uyarınca; sonsuz büyüklük toplam açısından bütünüyle düşünülemez. Kant sonsuz küçük ve sonsuz büyük olanın tasarımlanamaz oluşu düşüncesini Saf Aklın Eleştirisi’nde de sürdürür. Eleştirel dönemde görünüşlerle ilgili temel varsayımlardan biri, görünüş olarak her türlü gerçekliğin yoğunluklu [Alm. intensive] bir büyüklük olduğudur. ${ }^{36}$ Buna göre ne kadar küçük olursa olsun bir büyüklük yine de küçültülebilir. Dolayısıyla sonsuz küçük tasarlanamaz. Benzer biçimde 1770 tezinde sonsuz küçük ve sonsuz büyük olanın tasarımının olanaksız oluşu eleştirel dönemin antinomi düşüncesini çağrıştırır. Eleştirel dönemde aklın, uzay zamanda koşullu olanı koşulsuz olana taşıma isteği çatışkılara yola açacaktır. Bu bakımdan 1770 tezinde sonsuz küçük ve sonsuz büyük olanın tasarlanması sorunu eleştirel dönemde yetiler arasında yapacağı ayrıma hazırlar. Bu durumun kökenlerini Kant'ın şu sözlerinde görebiliriz: “anlayış yasaları ve akıl yasaları ile çatışan

32 Kant'a yapacağımız atıflarda Immanuel Kant, "On the Form and Principles of the Sensible and the Intelligible World [Inaugural Dissertation]”, içinde Theoretical Philosophy, 1755-1770, çev. David Walford (New York: Cambridge University Press, 1992), 373-416. çevirisini temel almakla birlikte, Immanuel Kant, "Dissertation on the Form and Principles of the Sensible and Intelligible World”, içinde Kant's Inaugural Dissertation and Early Writings on Space, çev. John Handyside (Chicago : London: The Open Court Publishing Company, 1929), 35-85. çevirisine de kullandık. Kant’ın kritik kavramları içinse Immanuel Kant, "De Mundi Sensibilis atque Intelligibilis Forma et Principiis”, içinde Kant's Gesammelte Schriften Preußische Akademie der Wissenschaften, c. 2, 1926.

$332: 387$.

$34 \quad 2: 387$.

$35 \quad 2: 388$.

36 Immanuel Kant, "Kritik der reinen Vernunft", içinde Kant's gesammelte Schriften Preußische Akademie der Wissenschaften, c. 3 (Berlin: Georg Reimer, 1911 A169-170/B211-212). 
her ne varsa kuşkusuz olanaksızdır" ${ }^{37}$ Kant ayrıca saf aklın [Lt. rationis purae] nesnesi olanın, görüsel bilginin yasaları alına getirilemeyeceğini de ekler. Her ne kadar anlayıs ve akıl yasalarının ne olduğunu hiçbir yerde açık etmese de duyusallık ile anlayı̧ arasında uyuşma olmadığının altını çizer. Dolasıyla Kant belirgin olarak duyulur olan ile anlaşılır olanı birbirinden ayırır. Kendinden önceki gelenek, örneğin Wolff bu ayrımı tasarımlar arasında seçiklik derecesine göre yapmış olsa da Kant yetileri besbelli biçimde ayırır. Eserin sonraki bölümlerinde ${ }^{38}$ de seçiklik derecesi yoluyla yapılan ayrıma karşı çıkar. Öyle ki, Kant açısından duyusal tasarımlar seçik, anlayışa ilişkin olanlar ise karışık bilinebilir [Lt. confusius cognitum]. Örneğin geometri duyusal bilginin seçik oluşunun örneğidir. Kendi yaklaşımının dışında kalan metafizikler ise anlayışla ilgileri açısından karışık bilebilmenin örnekleridir. Bununla birlikte Kant henüz anlayıs ve akıl arasında ayrım yapmamaktadır. Her ne kadar yukarıda aklın yasaları ve anlayışın yasaları anılmış olsa da bu ayrım ilkece değildir ve eserin ilerleyen bölümlerinde sürdürülmez. Saf Aklın Eleştirisinnin keskin biçimde ayırdığı bu yetiler 1770 tezinde birlikte düşünülür.

Duyusallık ve anlaşılırlık ayrımı uyarınca Kant, zihnin [Lt. mens] anlayıştan aldığı soyut idelerin [Lt. ideas abstractas] somut ve evriltilmiş biçimde görülere geri götürülemeyeceğini belirtir. İnsan zihnini çevreleyen kısıtlamalar şeylerin kendilerine yönelik kısıtlamalar olarak alınmamalıdır.

Kant bölüme dünya kavrayışını serimleyerek devam eder. Dünya, madde [L.t materia] "transendental anlamda [Lt. transecendentali] parçalar" ${ }^{39}$ ve formdan meydana gelir. ${ }^{40}$ Dünyanın maddesi tözlerdir. Kant burada Wolffçu çizgiyi koruyarak dünyanın çoklu öğelere dayalı yorumunu benimser. Dünyanın formu tözlerin bağıntıları aracılığıyla oluşur. Bu bağıntı Kant’a göre iki türlü meydana gelebilir. Ya bir eşgüdüm [Lt. coordinatione] ya da bir alt alta sıralanma [Lt. subordinatione] söz konusu olabilir. ${ }^{41}$ Birincisi karşılıklı ve homojendir [Lt. homonym]. Burada herhangi iki bağdaşık [Lt. correlatum] arasında diğerini belirleme, diğerince de belirlenme bağıntısı bulunur. İkincisi ise tek yönlü ve heterojendir [Lt. heteronyma]. Başka deyişle nedensel bir bağıntıyı işaret eder. Tözler arasında eşgüdüm bağıntısı ideal ya da öznenin seçimine göre değil, gerçek ve nesnel olarak düşünülür. Öyleyse tözler birbirleri üstüne etki edebilmektedirler.

Kant'ın dünyaya ilişkin yürüttüğü bir başka tartışma dünya durumlarının ardışıklığı ile mutlak bütünlük oluşu arasındaki bağıntıya yöneliktir. Dünya bir yandan sınırsızca durum çokluğundan meydana gelir görünmektedir. $\mathrm{Bu}$ durumda dünyanın bir bütünlük ortaya koyması ile töz durumlarının sınırsızlı̆̆ı nasıl bağdaşabilir? Kant bu noktada bir tasarım [Lt. repraesentationis] bütünlüğünün edinilebileceğini ama bütünlügün tasarımının edinilemeyeceğini savunur. Kant’ın çözümü tözler arasındaki eş zamanlılık, ardışıklık gibi bağıntıları duyusallıkla, bütünlük tasarımını ise anlayışla ilişkilendirmektir.

\section{$37 \quad 2: 389$.}

$38 \quad 2: 395$.

39 Eleştirel dönemin en önemli kavramlarından biri transendental burada yalnızca geçmektedir. Eleştirel bir kullanımı bulunmamaktadır.

$40 \quad 2: 389$.

$412: 390$ 


\section{Duyulur Şeyler ile Anlaşılır Şeyler Ayrımı}

Kant, 1770 tezinin ikinci bölümünde duyulurluk ile anlaşılırlık tartışmasını genişletir. $\mathrm{Bu}$ açıdan Kant’a göre duyusallık [Lt. sensualiteas] nesnenin [Lt. objecti] varlığı aracılığıyla öznenin tasarımsal [Lt. representativus] durumunun belirli biçimde etkilenmesini olanaklı kılan öznenin alırlığıdır [Lt. receptivitas]..$^{42}$ Burada eleştirel dönemde transendental estetik bağlamında ortaya konulan kavramların belirdiği görülür. ${ }^{43}$ Anlayıs [Lt. intelligentia] "özneye duyular yoluyla verilmeyen şeyleri tasarlama yetisidir" ${ }^{44}$. Kant duyusallığa konu edilen bilgilere phaenomenon ${ }^{45}$, anlayışa konu edilen bilgilere noumenon adını verir. Bilgi duyusallı̆̆ın yasalarına konu edildiğinde duyusal, anlayı̧ gücünün yasalarına konu edildiği ölçüde anlaşılabilir ve akılsaldır. Kant, duyusallıkta yer bulan bilgiyi (i) nesnelerin varlığına (ii) öznenin nesnelerden etkilenimine dayandığı ölçüde öznel varsayar. Şöyle der: "Açıktır ki duyusal olarak düşünülen şeyler, şeylerin belirdikleri/göründükleri [Lt. apparent] gibi tasarımlarıdır. Buna karşın anlaşılır şeyler, şeylerin oldukları gibi tasarlanmasıdır." ${ }^{66}$ Burada Kant eleştirel dönem kavramlarını kullansa da oradaki kavrayışından uzaktır. İlkin, eleştirel dönemde "duyusal olarak düşünülen” biçiminde bir yaklaşımdan cayacaktır. Saf ya da deneysel görüsel içerik olmadan anlama yetisinin kullanımını öngörmediğinden "duyusal olarak düşünülen” deyişi düşecektir. İkinci olarak noumenon eleştirel dönemde bilmenin konusu değil yalnızca düşünmeye konu edilebilen sınır çizici bir kavrayış olarak ele alınacaktır. Bununla birlikte Kant’ın duyusallık ve anlaşılırlık açısından bir gerilim yaşadığı ve bu ikisini nasıl ilişkilendireceği konusunda arayışta olduğu görülür.

Kant bir duyumun [Lt. sensus] tasarımında içerik [Lt. materiam] ya da duyumsama [Lt. sensatio] adı verilen yanla birlikte bir de form bulunduğunu bildirir. ${ }^{47}$ Dolayısıyla görünüşler zihnin [Lt. animi] belirli yasaları aracılığıyla belirli türde [Lt. speciem] düzenlenebilir. Bunun anlamı duyusal bilginin, duyusal içeriği düzenlemek sonucunda elde edildiğidir. Kant bu işlevi yerine getiren formu, taslak [Lt. adumbratio] ya da şema [Lt. schema] olarak değil, nesnenin varlığında nesneyi düzenleyen zihnin [Lt. mentis] içkin bir yasası olarak benimser. ${ }^{48}$

Anlayış [Lt. intellectualia] söz konusu olduğunda Kant burada elde edilen bilgiyi yetinin kullanım biçimleri üzerinden ayırır. Bu noktada Kant anlayısı, ruhun [Lt. animae] en yüksek yetisi [Lt. facultatis] olarak varsayıp iki tür kullanımı olduğunu öne sürer. (i) Real kullanım [Lt. usus realis] nesnelerin ya da bağıntıların kavramlarını veren kullanım; (ii) mantıksal kullanım [Lt. usus intellectus logicus] ne türde verilmiş olursa olsun ortak özellikleri bakımından kavramları birbirleri altında sıralayan [Lt. subordinantur] ve çelişmezlik ilkesine göre karşılaştırılan

42 2:392. Kant duyusallık için Latince sensualitas’ kullanır. Duyusallı̆̆a konu edilebilen içinse sensibile demektedir. Bu nedenle sensibile’i Türkçede duyulur ile karşıladık. Duyusallık yoluyla elde edilen bilgiyi nitelemek içinse sensitiva kullanır. Bunu ise duyusal ile karşıladık.

43 Krş. Saf Aklın Eleştirisi B1-A19/B33.

$44 \quad 2: 392$.

45 Kant duyusallığın nesnelerine fenomen adını verir. Phainō fiili Yunanca belirmek anlamına gelir.

$46 \quad 2: 392$

$47 \quad 2: 392$.

$48 \quad 2: 393$. 
kullanımdır. ${ }^{49}$ Mantıksal kullanım her bilim için geçerli olmasına karşın real kullanım değildir. Dolayısıyla her türlü bilginin temellerinde mantıksal kullanım bulunur. Bununla birlikte, Kant'ın eleştirel dönemde asla ilgilenmeyeceği bağlam anlayışın usus realisiyle elde edilen noumenal dünya olacaktır. ${ }^{50}$

Kant duyusallığın bilgi verebileceğini savlar. Bu bakımdan duyusal bir içerik verildiğinde anlayışın mantıksal kullanımı yoluyla duyusal tasarımlar birbirleriyle karşılaştırılarak bir sıradüzen içinde düzenlenir. ${ }^{51}$ Tüm deneysel bilimlerde yer alan duyusal tasarımlar anlayı̧̧ın mantıksal kullanımı yoluyla düzenlenir. Böylece fenomenlerin altında sıralanacağı genel fenomen yasaları ortaya konulur. Bununla birlikte duyum içeren bilgi, anlayışın mantıksal kullanımını içerse de duyusal olarak nitelenir çünkü Kant bilgiye niteliğini verenin kökeni olduğunu ileri sürer. $\mathrm{Bu}$ bakımdan Kant açısından geometri söz konusu olduğunda uzaydaki belirli bağıntılar olarak duyusal formun ilkeleri de duyusaldır çünkü anlayış onlarla mantık kurallarıyla uyumlu akıl yürütme yoluyla işlem yapsa bile saf görü aracılığılyla [Lt. per intuitum] verildiklerinden duyusaldirlar.

Duyusal [Lt. sensualibus] şeyler ve fenomenler açısından anlayısıı mantıksal kullanımını önceleyen görünüştür [Lt. apparentia].$^{52}$ Anlayıs yoluyla çok sayıda görünüş karşılaştırıldığında ortaya çıkan düşünümsel bilgi [Lt. cognitio reflexa] deneyimdir. Görünüşten deneyime geçilmesinin yolu anlayı̧ıın mantıksal kullanımı yoluyla düşünümdür. Bu bağlamda Kant deneyimin ortak kavramlarını deneysel [Lt. empirici] nesneler oldukları sürece fenomenler olarak niteler. Deneyimin yasaları ve genel olarak duyusal bilgi, fenomen yasaları olarak benimsenir. Bununla birlikte deneysel kavramlar her zaman duyusal kalır.

Anlayışın real kullanımında verilen kavramlar ya da bağıntılar kendi doğasından gelir. Kant bunların hiçbir duyusal bilgi formu içermediğini ve duyumların kullanımından soyutlanmış olmadıklarını öne sürer. ${ }^{53}$ Buna göre bir anlayış kavramı duyusal her şeyi soyutlar fakat duyusal olandan soyutlanmaz. Bu bakımdan Kant anlayış kavramına soyutlanmış [Lt. abstractus] yerine soyutlayıc1 [Lt. abstrahens] demeyi seçer. Dahası Kant anlayış kavramlarına saf ideler [Lt. ideas puras] adının verilmesini uygun bulur. Bir kez daha Kant'ın bu dönemde akıl ile anlama yetisi arasında ayrım yapmadığını, eleştirel dönemde altına herhangi bir görüsel içeriğin düşmediği ideleri bu sıralar bu bağlamda kullanmadığını belirtelim. Bu tartışma bağlamı içinde Kant’ın anlayışla ilişkilendirdiği bir başka alan ahlaktır. Eleştirel dönemin büyük ilgisi olan akıl yoluyla ahlak metafiziği ortaya koymayı andırırcasına 1770 tezinde Kant ahlaki kavramların deneyimle değil saf anlayıs yoluyla bilineceğini savunur.

\footnotetext{
$492: 393$.

50 James Ward, A Study of Kant (Cambridge: Cambridge University Press, 1922) 33.

$512: 393$.

52 2:394.

$532: 394$
} 
Anılan tartışmaların ardından bölüm metafizik hakkında soruşturma ile sürer. Kant’a göre saf anlayış gücünün kullanımının ilkelerini içeren felsefe metafiziktir. ${ }^{54} \mathrm{Ne}$ var ki, Kant metafiziğin olanağını temellendirmek yerine yalnızca bir başlangıç [Lt. propaedeutica] önerir. Bu başlangıç ise duyusal bilgi ile anlayıştan türetilen bilgiyi ayırmakla ilgilidir. Metafiziksel kavramlar anlayışın doğasında aranmalıdır. Üstelik doğuştan kavramlar [Lt. conceptus connati ] olarak değil zihne [Lt. menti] içkin yasaların deneyim sırasındaki edimlerinden elde edilmiş kavramlar olarak. Kant burada zihnin kendi işlemleri üstüne düşünerek taşıdığı olanakları deneyim dolayımıyla fark ettiğini serimliyor. Bu yolla farkına vardığı kavramlar olanaklılık [Lt. possibilitas], varoluş [Lt. exsistentia], zorunluluk [ Lt. necessitas], neden [Lt. causa] olarak açıklanıyor. Ne var ki, burada Kant açısından önemli bir sorun ortaya çıkar. Yukarıda değindiğimiz üzere, real kullanımında anlayış hiçbir duyusallık taşımamaktadır. Oysa şimdi Kant anlayış kavramları ile deneyim arasında bağ kurmaktadır. Bu sorun Kant'ın eleştirel dönemde transendental türetimi iki kez yazmasına yol açacak sorunla aynıdır: Anlama yetisi kavramlarının duyusallığa uygulanabilmesini haklılaştırma sorunu. Bu sorunun çözümü anlama yetisi kavramlarının türetimini gerektirdiğinden Kant yıllar sürecek bir çabayı sırtlayacaktır. Yeniden 1770 tezine döndüğümüzde Kant’a göre anlayı̧ kavramları tasarımların [bir parça olarak] içeriğine katılmaz ya da duyusal bir tasarımdan soyutlanma yoluyla elde edilemez. Bununla birlikte örtüşmez yanlarına karşın anlayı̧̧ kavramları düşüncesinin Kant’’n eleştirel dönemindeki kategori öğretisinin ilksel biçimi olduğunu söylemek yanlış olmayacaktır.

Kant'ın bölümdeki bir diğer tartışması anlayıs kavramlarının kullanımı hakkındadır. Buna göre burada çürütücü [Lt. elencticus] ve dogmatik [Lt. dogmaticus] olmak üzere iki kullanım bulunur. ${ }^{55}$ Kant'ın olumsuz olarak nitelediği çürütücü kullanım, duyusal olarak anlaşılanı noumenondan ayrı tutmaya yarar. Kant açısından böylesi bir kullanım anlayışı duyusallıktan gelen sızıntılara karşı koruyacaktır. Anlayışın dogmatik kullanımı ontoloji, akılsal psikoloji ve teolojide yer alarak bir paradigmaya [Lt. exemplar] yol açar. Böylesi bir paradigma ancak saf anlayı̧ yoluyla kavranır ve şeylerin ortak ölçüsü olarak görülür. Kant'a göre bu paradigma noumenal yetkinliktir [Lt. perfectio noumenon ${ }^{56}$. Teorik ve pratik anlamda yetkinliktir. Teorik yetkinlik anlamında en üstün varlık [Lt. ens summum] Tanrı'dır [Lt. Deus]. ${ }^{57}$ Tanrı bir yetkinlik ideali olarak bilmenin ilkesini meydana getirir. Benzer biçimde yetkin ne varsa varoluşa gelmesinin kaynağı Tanrı'dır. Kant'a göre tözlerin çokluğu tek bir dünyayı ancak bütün tözlerin dayanağı ortaksa oluşturabilir. Bu yüzden bu dünyanın temeli Kant’a göre Tanrı'dır. Bu görüş Kant’ın öteden beri savunduğu fakat eleştirel dönemde savunmayacağı görüşlerden biridir.

Pratik bakımdan yetkinlik ise ahlaki yetkinliktir. Kant bir kez daha ahlakı, anlayışla üstelik saf anlayışla ilişkilendirir. Ahlakın olanağı anlayış yoluyla bilinebilir ve saf felsefede ele alınır. Bu açıdan ahlaki yargıların ilkelerinin kaynağı saf anlayıştır. 
Kant anlayışın dogmatik kullanımını açıklarken bir kısıtlama ortaya koyar. Buna göre anlayışta şeylere ilişkin görü [Lt. intuitus] bulunmaz, fakat yalnızca onların simgesel [Lt. symbolica] bilgisi bulunur. ${ }^{58}$ Anlama [Lt. intellectio] somuttaki tekil kavram yoluyla değil soyuttaki tümel kavramlar yoluyla olanaklıdır. Öyleyse Kant, duyusallığa konu edilen bilgi ile anlayışa konu edilen bilgiyi tekillik-tümellik karşıtlığı üzerinden de ayrıştırır. Ona göre tüm görüler belli bir form ilkesine bağlıdır ve ancak bu form yoluyla zihin [Lt. mente] aracilığıyla dolaysızca ya da tekil olarak kavranılabilir. Tümel kavramlar aracılığıyla gidimli olarak değil. Görünün biçimsel koşulu olan uzay ve zaman bir şeyin duyuların nesnesi [Lt objectum] olmasının koşuludur. Buna karşın noumena duyusallıktan elde edilen tasarımlar yoluyla kavranamaz. İşte bu nedenle anlayıştaki simgesel bilgi burada gereklidir. Fakat bununla birlikte büyük bir sorun ortaya çıkar: Anlaşılır dünya hakkında öne sürülenlerin doğruluğuna nasıl karar verebiliriz? Bu tür önermeleri imgelemin oyunlarından ya da düşlerden nasıl ayırt edebiliriz? 1770 tezi açısından bu sorunun yanıtı belirgin değildir.

Kant bölümü kapatırken fenomenlerin yapısı ve gerekçelendirilmesi hakkında bir tartışmaya girer. Bu bağlamda fenomen, nesne olarak duyularla bağlantılı her şeydir. Fenomenler şeylerin çeşitleridir [Lt. species], idelerin [Lt. idae] değil. Fenomenler dişsal duyu durumunda fizikte, içsel duyu durumunda deneysel psikolojide araştırılır. ${ }^{59}$ Fenomenler nesnelerin içsel ve mutlak niteliklerini ortaya koymaz. Yine de fenomenlerin bilgisi yüksek doğruluk taşır. Bunun nedeni duyusal kavram ya da kavrayış oldukları sürece, nedensel şeyler olarak, bir nesnenin varlığına bağlı olmalarıdır. ${ }^{60}$ Böylelikle 1770 tezinde idealizme karşıt olarak duyulur dünyanın hakiki deneysel bilgisinin olanaklı olduğunu görürüz. Deneysel bilginin hakikiliğini Kant şu varsayımlara dayandırır: (i) fenomenlere ilişkin yargılar, özne ile yüklemin uyuşmasından meydana gelen doğruluk koşuluna uyar (ii) bu tür yargıların hem yüklemi hem öznesi duyusaldır. ${ }^{61}$

Bölümün sonunda Kant saf görüyü ele alır. Burada duyulara dokunmayan yalnızca duyusallığın tekil formunu içeren şeyler saf görüye ilişkin olarak belirlenir. Başka deyişle saf görü duyumdan bağımsız fakat aynı nedenle anlayıştan türetilemeyen görü türüdür. Öyle ki onun saflığı anlayışın mantıksal ya da real kullanımıyla ilgili değildir. Kant uzay ve zamanın $a$ prioriliğini andırırcasına görülerin saflığını vurgular. İnsanın saf görüsü, tümel ya da mantıksal kavram değil fakat içinde her türden duyulur şeyin düşünüldüğü tekil bir kavramdır.

Saf görü uzay ve zaman kavramlarını içerir. Bu kavramlar duyusal şeyleri nitelikleri bakımından belirleyemediklerinden nicelik dışında bilimin konusu değildir. Saf matematik geometride uzayla, saf mekanikte zamanla ilgilenir. Bu kavramlara ek olarak anlayışa ait olan fakat somutta edimselleştirilmesi için uzay ve zaman kavramlarına gereksinim duyan, belli şeyleri ardışık olarak ekleyen ve eş zamanlı olarak bu şeyleri ayıran sayı kavramı vardır ve bu da Kant açısından aritmetiğin konusudur. 


\section{Duyulur Dünya Üstüne}

1770 tezinin üçüncü bölümü duyulur dünyanın formları olarak ele aldığı uzay ve zaman hakkındadır. Kant'ın burada ortaya koydukları Saf Aklın Eleştirisinnin transendental estetik bölümünde büyük oranda yinelenir.

Yukarıda andığımız gibi 1770'ten önceki 1768 eserinde Kant, Newtoncu mutlak uzay anlayışı üzerinden Leibnizci göreli yaklaşımı eleştiriyordu. Fakat bu eleştirinin uzaya yönelik ontolojik bir bağlanma üzerinden olmadığını gösterir biçimde Kant şunları söyler: "Mutlak uzay dışsal duyumun bir nesnesi değil temel bir kavramdır"62. Öyleyse Kant, uzayın bir mutlaklık içerdiğini düşünse de buna bir varlık yükleme eğilimde değildir. Bu ise onun Newtoncu uzay anlayışını tümüyle benimsemediğini ortaya koyar. 1770 tezi, 1768'de açıklanmayan uzayın ne türde bir "kavram” olduğunu zamanı da katarak açıklar. Söz konusu açıklamanın ilk aşaması duyulur ile anlaşılır olanın bölümlenmesidir. Bu yolla Kant, duyulur dünyanın formunun ilkesini fenomen oldukları sürece tüm şeylerin tümel bağıntılarının zemini olarak ortaya koyar. ${ }^{63}$ Duyulur dünyanın formunun ilkesi kendinde varolan şeylerin bir araya getirilişini sağlayan bir neden hakkındadır. Dünya, bir fenomen olarak alındığında, başka deyişle duyusallıkla bağıntı içinde dünya, öznel bir ilke tanır. Ne var ki, bu ilke, zihnin sabit, öznel bir ilkesidir ve duyulara konu edilebilecek tüm şeylerin zorunlulukla aynı tümlüğe ait olmasının zorunlu oluşunu sağlar. ${ }^{64}$ Demek ki, duyulur dünyanın ilkesi hem öznel hem zorunludur. Böylece Kant duyusallığı zorunlu bir yeti olarak ele aldığını ortaya koyar. Duyulur dünyanın formunun ilkesi, duyulara konu olan edimsel şeylerle ilgili olmasına karşın maddi olmayan tözler ve dünyanın nedeniyle ilgili değildir. Kant, sıkı biçimde fenomenal evrenin formel ilkelerinin mutlak olarak ilksel ve tümel olduğunu belirtir. ${ }^{65}$ Öyle ki, bu ilkeler; uzay ve zaman insan bilgisindeki duyusal her şeyin koşulları ve şemalarıdır.

Bölümün devamında Kant duyulur dünyanın ilk formu olarak zamanı konu eder. Saf Aklın Eleştirisi’nin transendental estetik bölümü ise önce uzayı ele alacaktır. Sonraki yaklaşımı ile 1770'teki yaklaşımı arasındaki bir başka önemli ayrım henüz transendental ve metafiziksel açımlama [Alm. Erörterung] anlayışının bulunmamasıdır. Bu durum 1770 tezinde Kant’’n duyusallığın formlarını haklılaştırma ve gerekçelendirme aşamasında olmadığını da gösterir. Bunun için ayrılan duyulur ile anlaşılan dünyanın yeniden bağlantılı olmasını sağlayacak bir düşünme tarzı gerekecektir.

\subsection{Zaman Üstüne}

Kant 1770 tezinde zamanla ilgili şu saptamaları yapar:

1. Zaman idesi [Lt. idea] duyulardan kaynaklanmaz duyular için önden varsayılır. ${ }^{66}$ Çünkü duyular ancak zaman koşullarında önüne gelen şeyleri eş zamanlı ya da ardışık olarak 
tasarımlayabilir. Dolayısıyla zaman ardışıklıktan türemez. ${ }^{67}$ Zaman birbirlerinden sonra gelen şeylerden türeyemez, çünkü "sonra" anlamını zamanda kazanır. Tüm zamanlar aynı zamanın içindedir. 1770 tezinde Kant a priori deyişini kullansa $\mathrm{da}^{68}$ eleştirel döneminde olduğu gibi kurucu bir yer vermez. Bundan dolayı "zaman a prioridir" demektense duyular için önden varsayılır demektedir.

2. Zaman idesi, genel değil tekildir. ${ }^{69}$ Önce ve sonra ancak zamanın bir görü olması ile anlaşılır.

3. Zaman idesi bir görüdür. ${ }^{70}$ Kant daha önce zamanın bir saf görü olduğunu da bildirmişti. ${ }^{71}$ Tüm edimsel şeyler zamana yerleştirilerek anlaşılır. ${ }^{72}$

Kant'ın zamanın tasarımlanmasına ilişkin ortaya koyduğu bu üç yan Saf Aklın Eleştirisinnin transendental estetik bölümünde metafiziksel açımlamada korunacaktır. İzleyen dört yan ise transendental açımlamada korunur.

4. Zaman sürekli bir büyüklüktür. ${ }^{73}$ Bu yaklaşım transendental estetik bölümünde bulunmasa bile Kant zamanın sınırsızca bölümlenebileceğini Eleştiri'de savunur. Zaman evrenin değişimi içinde sürekli olanın yasalarının ilkesidir. Zamanın her parçası zamandır. ${ }^{74}$ Zamanın tek boyutu vardir.

5. Zaman, nesnel ve gerçek [Lt. reale] bir şey değildir. Zaman bir töz, ilinek ya da bağıntı değildir. Zaman, insan doğasının bir sonucu olarak, sabit bir yasaya göre tüm duyusal şeyleri düzenleyen öznel koşuldur. ${ }^{75}$ Burada Kant'ın zamanın ontolojik durumu ile ilgilendiği görülür. Zaman kavramı aracılığıyla tözler ve ilinekler arasındaki bağıntıları eşzamanlı ya da ardışık olarak düzenlemek olanaklı olur. Zaman töz ve ilinekten önce olmalıdır ki onlar arasındaki bağıntılar anlaşılabilir olsun. Newtoncular zamanı tüm var olanlardan bağımsız sürekli bir akış olarak ele alarak Kant açısından "saçma bir uydurmaca" içindedirler. ${ }^{76}$ Leibnizciler içinse zaman içsel durumların sürekliliğinden soyutlanmış gerçek bir şey olarak tasarlanır. Kant’a göre bu durumda zamanın önemli bir sonucu olan eşzamanlılık yok sayılır. ${ }^{77}$

Zaman kavramı doğuştan bir görü değildir ve bütünüyle ruhun [Lt. animi] iç yasasına dayanır. Bundan dolayı, ruhun duyumsadıklarını düzenlerken gerçekleşen edim, duyuların yardımı olmaksızın elde edilemez. Çelişmezlik ilkesi de zaman kavramını gerektirir. Aynı şeyin

$67 \quad 2: 399$

68 2:417'de ve 2:418'te geçmektedir.

$692: 399$.

$70 \quad 2: 399$.

$712: 392$.

$72 \quad 2: 399$ ve $2: 392$.

$732: 399$.

$742: 400$.

$75 \quad 2: 401$

$76 \quad 2: 400$

$77 \quad 2: 401$. 
hem A, hem de A olmayan olması eş zamanlı olmadığı sürece tutarsız değildir çünkü bu durum peş peşe gerçekleşebilir.

6. Zaman duyuların bütün olanaklı nesnelerinin görüsel tasarımının koşuludur. Ancak bu koşul altında bütün gözlenebilir olaylar, bütün hareketler, bütün iç değişiklikler, duyuların nesneleri düzenlenebilir.

7. Zaman, duyusal dünyanın mutlak olarak ilk formel ilkesidir. ${ }^{78}$

Kant'ın zamana ilişkin dile getirdiği 6. ve 7. yanlar eleştirel dönemin dili ile söylenecekse deneysel olarak gerçek ve transendental olarak idealdir. 1770 tezinde duyulur şeylere ilişkin en yüksek dereceden doğru olarak ele alınır. ${ }^{79}$

\subsection{Uzay Üstüne}

Kant uzay hakkında ise şu belirlemeleri yapar:

1. Uzay kavramı dışsal duyumlardan soyutlanmaz çünkü bir şey ancak öznenin bulunduğu yerden farklı bir yerde tasarlanarak anlaşılabilir. ${ }^{80}$ Dış algıların olanağı uzay kavramını gerektirir. Uzaydaki şeyler duyuları etkileyebilir ancak uzay duyulardan çıkmaz. Burada Kant’ın uzayın türetilemez oluşuna ve önceden varsayılmasına yönelik dile getirdikleri Saf Aklın Eleştirisi’nde uzayın a priori olduğunu gerekçelendirirken savunacağı varsayımlardan olacak.

2. Uzay kavramı bütün şeyleri içeren tekil bir tasarımdır. "Birçok yer" aynı sınırsız uzayın parçasıdır. Kant uzay genelliği ile belirli uzayları ayırır. Belirli uzaylar genel uzay kavramının altına düşer. Belirli uzayların parçaları da aynı sınırsız uzayın içinde yer alır.

3. Uzay duyusal dünyanın ilk mutlak formel ilkesidir. Bütün dışsal duyumun temel formudur. Bu kavram aracılığıyla evrendeki nesneler fenomen olur.

4. Uzay kavramı saf bir görüdür. Kant’a göre uzayın saf görü oluşu geometrinin aksiyomlarında kolaylıkla görülebilir. ${ }^{81}$ "Uzayın üçten fazla boyutu olamaz", "İki nokta arasında yalnızca bir düz çizgi vardır” gibi önermeler herhangi bir tümel uzay kavramından türetilemez, ancak uzay içinde somut kavranabilirler. ${ }^{82}$ Kant'ın uzayın bir görü oluşuna ilişkin temel varsayımlarından biri, sağ el ve sol el gibi birbirine benzer hatta eş cisimler arasında, bu cisimlerin uzanımlarının uyuşmamasına yol açan bir ayrımın bulunmasıdır. Bu ayrım ancak saf görüyle kavranılabilir. Kant aynı konuyu iki yerde daha ele alır: Yukarıda değinildiği gibi Uzaydaki Yönler'de sol ve sağ el arasındaki ayrım, birini çevreleyen yüzeyin diğerini çevreleyememesinden dolayıdır. Prolegomena'da ise uzayı ve zamanı kendi başına şeylerin niteliği olarak görenlerin çözemeyeceği bir sorun olarak, tüm parçaları bakımından bütünüyle 
aynı olan şeylerin, -örneğin sağ el sol el ya da sağ kulak sol kulak çiftinin- birbirleri yerine neden konulamayacağını ortaya koyar. $^{83}$

5. Kant'a göre uzay nesnel ve gerçek bir şey değildir. Uzay bir töz, ilinek ya da bağıntı da değildir. Uzay insan doğasından kaynaklanan sabit bir yasaya göre dış dünyadaki duyulur şeyleri alt alta yerleştiren öznel koşuldur. ${ }^{84}$ Kant açısından, Newton gibi uzayın kendinde gerçekliği olduğunu düşünenler başka deyişle uzayı var olanları içeren mutlak ve sınırsızca bir şey olarak tasarlayanlar ya da Leibniz ve izleyicileri gibi, uzayı var olan şeyler arasında bir bağıntı olarak tasarlayanlar yanılırlar. Bu bakımdan gelenekte yer alan uzay anlayışları Kant’a yetmez. Uzayı bağıntı olarak görenler geometriyi yüksek kesinlikten deneysel kesinliğe indirger. Uzayın tüm özellikleri dış bağıntılar yoluyla deneyimden alınırsa, geometrinin aksiyomları zorunluluk ve genel geçerlik taşımaz.

6. Her ne kadar uzay kavramı, nesnel ve real varlık ya da özellik olarak imgesel [Lt. imaginarius] olsa bile yine de her türden duyulur şeyler bağlamında en yüksek dereceden doğruluk taşır. ${ }^{85}$ Uzay aynı zamanda dışsal duyarlıktaki [Lt. sensualitate externa] bütün doğruların temelidir. Çünkü duyarlığın yasaları, ancak doğa duyuları etkilediğinde, doğanın yasaları olabilir. Böylece doğa, geometride kullanılan uzayın özellikleri bağlamında geometrinin kurallarına bütünüyle konu edilir. Bu durum kurmaca bir varsayım temelinde değil, bütün fenomenlerin öznel koşulu olan görü aracılığıyla gerçekleşir. Uzay kavramı ruhun doğasınca verilmezse, doğa felsefesinde geometrinin kullanımı güvenilir olmaktan uzak olur. Çünkü uzay kavramının deneyimden türetildiğinden kuşku duyulabilir.

Kant bölümü kapatırken duyusal ile anlayışa dayalı bilgi ikiliğini yineler. Duyusal bilgi, anlayışın tasarımlarından farklı olarak genel kavramlar ama tekil saf görülerdir. Bu görülerde parçalar, özellikle basit parçalar bir bileşiğin olanağının temelini içermez. Parçaların sınırlandırılmış [Lt. limes] biçimde düşünülmesinin temeli uzay ve zamanın sonsuzluğudur. Bir nokta ya da an, uzay ve zamanın sınırlandırılması altında olmadan kendinde düşünülemez. Kant’a göre uzay ve zaman kavramlarına ilişkin belirlenimlerin anlayı̧s kavramları açısından açıklanamaz oluşu bunların aklın sınırlarının ötesinde durduğunu gösterir. ${ }^{86}$ Bununla birlikte "Bu kavramlar [uzay ve zaman], mantık yasaları ve olanaklı en yüksek kesinlik ile uyumlu olarak anlayışın dayandığı temelleri oluşturur. Anlayıs görünün ilksel verisinden sonuçlar çıkarır." ${ }^{87}$ Burada Kant anlayışın mantıksal kullanımını anmaktadır. Kant bu kavramlardan birinin [uzayın] nesnenin görüsünü, öbürünün [zamanın] ise durumunu özellikle de tasarımsal durumunu ilgilendirdiğini belirtir. Bununla birlikte uzay bir imge [Lt. typus] olarak zaman kavramının kendisine uygulanır; zamanı

83 4:285.Immanuel Kant, "Prolegomena zu Einer Jeden Künftigen Metaphysik, die als Wissenschaft Wird Auftreten Können”, içinde Kant's gesammelte Schriften Preußische Akademie der Wissenschaften, c. 4 (Berlin: Georg Reimer, 1911).

$842: 403$.

$852: 404$.

$862: 405$.

$87 \quad 2: 405$ 
bir çizgiyle, sınırlandırmalarını [terminos] (anlarını) noktalarla tasarlar. ${ }^{88}$ Zaman tümel ve akılsal bir kavram olmaya daha yakındır; bağıntılarında tüm şeyleri içerir, uzayın kendisini de içerir, hatta, zihindeki [Lt. mens] düşünceler gibi uzaysal bağıntılarda içerilmeyen ilinekleri de kapsar. Dahası zaman, akla yasalar koymamakla birlikte yine de aklın yasalarıla uyumlu olarak zihnin kavramlarını karşılaştırabileceği temel koşulu oluşturur. ${ }^{89}$ Kant açısından A ile A-olmayanın aynı özneye aynı anda yüklenememesi zaman aracılığıyla gerçekleşir. Benzer biçimde deneyimde anlayışıı durumuna bakılırsa, en azından dişsal nesneler açısından düşünülen neden ve sonuç bağıntılarının, uzay bağıntılarını gerektirdiği görülür. ${ }^{90}$ Bunun gibi tüm dış ve iç nesneler ancak zamanın yardımıyla önce ya da sonra, yani neden ya da sonuç olarak düşünülebilir. Uzayın niceliği ölçü olarak bir birim ile ilişkilendirilmeden ve bir sayı ile ifade edilmeden anlaşılır değildir. ${ }^{91}$ Böyle bir sayı ise saymadan eş deyişle verilen bir zamanda ardışık olarak bire bir eklemeden ayrı bir büyüklüktür.

Kant'ın bölümde yürüttüğü son tartışma uzay ve zamanın kökenine yöneliktir. Bu bağlamda Kant uzay ve zaman kavramının doğuştan mı yoksa kazanılmış mı olduğunu tartışır. Kant’a göre uzay ve zamana ilişkin yukarıda dile getirdiğimiz görüşler bu kavramların kazanılmadığını kanıtlamışır ancak doğuştan oldukları da kaba biçimde söylenmemelidir. Bu kavramların her biri kazanılmıştır fakat nesnelerin duyulanışından soyutlanarak kazanılmamışlardır. Çünkü duyumlar yalnızca bilginin içeriğini verir, insan bilgisinin formunu vermezler. Bu kavramlar duyumlananları, değişmez yasalara göre düzenleyen zihnin [Lt. mentis] hareketinden kazanılır. Kant uzay ve zamanı görüsel olarak bilinen değişmez imgelere [Lt. connatus] benzetir. ${ }^{92}$ Burada doğuştan olan zihnin yasasıdır ve onun aracılığıyla nesnenin varlığında duyu izlenimleri belirli bir biçimde bir araya getirilir. ${ }^{93}$ Üstelik duyusal görünün nedeni ancak anlayı̧ yoluyla bilinebilir. ${ }^{94}$

Layvine, Kant'ın duyulur dünyanın ilkeleri uzay ve zamanı bizim deyişimizle "Tanrılaştırmasına" dikkat çeker. ${ }^{95} 1770$ tezinde duyusallık, daha önce denetimi altında kaldığ anlayıştan bağımsızlaşır. Öyle ki, anlaşılır dünyanın ilkesi olan Tanrı'ya yüklenen nitelikler, duyulur dünyanın ilkeleri uzay ve zaman için de geçerlidir. Buna göre Tanrı sonsuzdur, uzay zaman da; Tanrı sonsuz yetkinlik barındırır, uzay sonsuz yer, zaman sonsuz an; Tanrı, uzay ve zaman basit, eşsiz ve biricik olarak kendi dünyalarının ilkeleridir.

88 SAE B154'te zaman çizgi zamanın dışsal tasarımı olarak betimlenir.

$892: 406$

90 Bu yaklaşım SAE A211-8 / B256-65 üçüncü analoji ile kategorik ilkelerin uzaysal şematizmi önceler. Aynı zamanda Kant burada içeriksel idealizmin çürütülmesi B274-9 tartışmalarını da önceler.

91 SAE A142-3/B182.

92 2:406.

93 SAE B167-8.

$942: 409$.

95 Alison Layvine, "Kant's Early Metaphysics and the Origins of the Critical Philosophy", içinde North American Kant Society Studies in Philosophy, ed. Manfred Kuehn ve Karl Ameriks, c. 3 (California: Ridgeview Publishing Company, 1993) $113-4$ 


\section{Anlaşılır Dünya Üstüne}

Kant'ın anlaşılır dünya bağlamında tartıştığı temel konu birbirlerinden farklı tözlerin nasıl bir dünya oluşturduklarının ele alınmasıdır. Sorun form üzerinden ele alınır. Töz çokluğu nasıl olur da bir toplam meydana getirir. ${ }^{96}$ Uzay, tözlerin birlikli bir dünya oluşturmaları için gerekli koşul olsa da yeterli koşul değildir. Sorun ancak anlayışa başvurarak çözülebilir. Tözlerin birlikte varoluşu da aynı biçimde yeterli değildir çünkü tek başına böylesi bir koşul tözlerin karşılıklı bağıntıları için bir zorunluluk sağlamaz. Daha sonra Kant, zorunlu olarak var olan tözlerden oluşan bir dünyanın da olanaksız olduğunu öne sürer çünkü bu durumda böylesi tözler varoluşlarında yalnızca kendilerine dayanmak durumundadır. ${ }^{97}$ Zorunlu olarak var olmayanın olumsal bir varoluşu bulunduğundan, dünya olumsal tözlerden meydana gelmek durumundadır. Buradan da olumsallıklarından ötürü tözlerin başka bir varlığa dayandığı sonucuna ulaşılır. Birlikli bir dünya için tözlerin etkileşimi gerekli olduğundan, evrendeki tözlerin bağlaşımı içindeki birlik, tüm tözlerin tek bir varlığa dayanmalarının sonucudur. ${ }^{98}$

Tözler arasındaki bağlantı zorunludur çünkü tüm tözler artık ortak bir ilke altında ve ortak yasalar uyarınca yönetilebilir. ${ }^{99}$ Kant böylesi bir durumu "genel olarak kurulmuş düzen" olarak niteler. Ancak böylesi bir düzen altında uyum gerçek ve fiziksel olabilir.

$\mathrm{Bu}$ bölümdeki önemli bir sorun Johann Friedrich Schultz'un (1739-1805) da 1770 tezi hakkındaki değerlendirmesinde ortaya koyduğu üzere, tözlerin birlikli bir bütün olarak bağlantılarının tek bir zorunlu varlığa dayanmaları yoluyla açıklanmış olmasının temelsiz oluşudur. Bir başka sorun tözler arasındaki etkileşimin değişime karşılık gelmesidir. Değişim zamansallık gerektirir, zamansallık ise duyulur dünyaya ilişkindir. Lambert'in 13 Ekim 1770 mektubunda dikkat çektiği bu konu bir sorundur. Bu noktayı sonuçta yeniden ele alacağız.

\subsection{Metafizik Üstüne}

Yukarıda dile getirdiğimiz üzere 1770 tezinde Kant metafiziğe ilişkin giriş önermektedir. Bu önerinin temel varsayımı ise duyusallıktan gelen bilgi ile anlayıştan gelen bilginin ayrıştırılmasıdır. Kant temel tezini açımlamak için bölüme bir yöntem tartışması ile başlar. Saf Aklın Eleştirisi’nde olduğu gibi yöntem matematik ve doğa bilimleri göz önünde bulundurularak tartışılır. Duyusal görü aracılığıyla verilen temel kavramlar ve aksiyomlar açısından bilimlerde anlayışın kullanımı mantıksal kullanımdır. Bu kullanımda çelişmezlik ilkesi uyarınca tümellik bağlamında bilgiler alt alta sıralanır. Söz konusu bilimlerde kazanılan başarılar buralarda yeni yönteme gerek olmadığını gösterir oysa metafizik için durum başkadır. Metafizik henüz bir bilim olarak kurulmadığından olanağı araştırılmalıdır. ${ }^{100}$ Tam bu noktada Kant bu olanağa kapsamlı bir biçimde yaklaşmak yerine metafizikte kendine kadar yapılan yanlışa odaklanır. Bu yanlış, anlayışa ilişkin bilgiye duyusallıktan gelen bilginin sızmasıdır. ${ }^{101}$ 
Dolayısıyla duyusal bilginin sınırlarını aşarak anlayı̧̧a ilişkin olana geçmesi engellenmelidir. ${ }^{102}$ Yinelemek gerekirse Kant açısından duyusal bilginin ilkelerini, nesnelerin kendileri hakkındaki ilkelerden ayırmak metafizik için gereklidir. Bu durumun sınanacağı bağlam ise yargılardır. Metafiziği yargıların çözümlenişi üzerinden konu etmek Kant’ın eleştirel dönemde de sürdürdüğü bir tutumdur.

1770 tezinde bir yargının kuruluş biçimi ile metafiziksel bilginin durumu arasında bağ kurulur. Kant bir yargının yüklemi anlayış kavramı olduğunda, bu yüklemin öznesiyle bağıntısının, özne duyusal olsa bile, nesnenin kendisine ilişkin bir özellik dile getirdiğini varsayar. Fakat yüklem duyusal bir kavram ise duyusal bilginin ilkeleri şeylerin kendilerinin olanağı hakkında olmadığından nesnel olmayacaktır. Yüklem duyusal kavram ise yalnızca olanaklı duyusal bir bilginin koşulu olur ve duyusal olan bir yargının öznesi ile uyumlu olur. ${ }^{103}$ Duyusal yüklem, öznenin anlayış kavramı olduğu bir yargıda durursa yargı yalnızca öznel olur.

Kant duyusal bir kavram sanki anlayı̧stan türetilmiş belirleyici bir özellikmiş gibi kullanıldığında yanılsama [Lt. praestigiae, İng. illusion] ortaya çıktığını savunur. Bu yanılsamaları yanıltma [Lt. subreptionis, İng. subreption] olarak adlandırır. ${ }^{104}$ Bunlardan anlayışı aldatan, metafiziğin bütününe yayılan ilkeler türer. Böylece Kant, duyusallığın koşullarından metafiziksel bilgi türetmenin yanılsamalara yol açtığını belirterek antinomi düşüncesine yaklaşır. Her türden yanıltmanın temelini şöyle dile getirir: "anlayışın herhangi bir kavramı uzay ve zaman bağıntılarına ilişkin bir şeye yüklenirse nesnel olamaz; o yalnızca yokluğunda verilen kavramın duyusal olarak bilinemeyeceği koşula gönderim yapar." ${ }^{105}$ Dolayısıyla duyusallık nesnellikle ilgili görülmemelidir. Bununla birlikte Kant açısından görü aracıllğıyla bilinemeyen herhangi bir şey düşünülemez. Burada Kant zihinsel bir etkinlik yoluyla uzay ve zaman formları ile uyumlu başka türlü bir görünüm elde edilemeyeceğini düşünür.

Kant açısından duyusal bilginin kendini anlayıs bilgisi kılığına sokmasıyla ortaya çıkan yanılsamaları üç çeşide indirgenebilir ${ }^{106}$ :

1. Bir nesnenin yalnızca görüsünün olanaklı olduğu aynı duyusal koşul, aynı zamanda nesnenin kendisinin olanağının da bir koşuludur.

2. Bir nesnenin anlayış kavramını oluşturmak için verileni karşılaştırmanın olanaklı olduğu duyusal koşul, aynı zamanda nesnenin kendisinin olanağının da bir koşuludur.

3. Verilen bir anlayış kavramı altında içerilebilen, tek bir nesnenin karşılaşığı aynı duyusal koşul aynı zamanda nesnenin kendisinin olanağının da bir koşuludur.

Birinci çeşidin yanıltıcı aksiyomu şudur: "Ne varsa bir yerdedir ve bir zamandadır"107. Kant'a göre bu düzmece ilkeyle bütün varlıklar sanki anlayış̧̧ biliniyormuşçasına uzay ve zamanın 
koşullarına bağlanır. Buradan yola çıkarak cisimsel olamayan tözlerin, ruhların, Tanrı'nın yeri, etkileşimleri, bedensel varlıklarla bağıntıları üzerinden "Tanrı dünyayı yüzyıllar önce neden oluşturmadı?" "Kendisinin olmadığı bir zamanda Tanrı şeyleri nasıl görür?” "Ruh bedeni nasıl hareket ettirir" türünde boş [Lt. inanes] sorunlar gündeme gelir. Ne var ki, Kant açısından bu sorunların çözümü için gereken nesnellik, duyusallık koşulları anlayış kavramlarına yüklendiğinde sağlanamaz. Oysa "zaman kavramı düzgün anlaşıldığında duman gibi dağılıp gider"108. Kant açısından bu tür yargıların düzeltilmesinin bir başka yolu da yargıyı yeniden düzenlemektir. Yargı değiştirilip yüklem anlayış kavramı yapıldığında doğru olur ve şuna dönüşür: "Her ne bir yerdeyse var olur" ${ }^{109}$

İkinci yanıltıcı aksiyom türü ilkinden daha karmaşıktır. Kaynağı duyusal koşulların belirli anlayış kavramlarının kavranmasında içerilmesidir. Bu nedenle, duyusal koşullarda olanaklı olan ile anlayış yoluyla düşünülen birleştirilir. Kant bu durumu nicelik ve nitelik üzerinden iki örnekle açıklar: (i)her edimsel çokluk [Lt. multitudo, İng. multiplicity] sayısal olarak verilebilir bundan dolayı her büyüklük [Lt. quantum, İng. magnitude] sonludur. (ii) her ne, olanaksız ise kendisiyle çelişir. ${ }^{110}$ Kant açısından her iki yargıda da zaman kavramı yüklem kavramının kendisine girmese de ona bir form vermenin aracısıdır. ${ }^{111}$

Her büyüklük ve her dizi ardışık eşgüdüm [Lt. coordinationem succesivaim] aracılığıyla seçik olarak bilinir. Ardışık eşgüdüm bir anlayış kavramıdır. Anlayış bu kavramı zaman kavramı yardımıyla oluşturur. Bu oluşum ancak sonlu zamanda gerçekleşirse tamlık sağlanır. Fakat sonsuz dizilerin oluşumunun sonlu zamanda gerçekleşmesi olanaklı değildir. Eşgüdüm dizisinin sonlu dizisi anlayışın kısıtlamalarından dolayı seçikçe kavranamaz. Saf anlayış yasaları uyarınca, nedensellik altında şeylerin kendi ilkesi bulunur. Başka bir deyişle, nedensellik altında şeylerde sınırsı bir gerileme yoktur. Duyusallığa ilişkin yasalara göre herhangi bir eşgüdüm dizisi kendi başlangıcını taşır. Böylece Kant bir eşgüdüm dizisinde duyusallık uyarınca ölçülebilirlik ile anlayı̧ uyarınca bağımlılığı özdeş kılmanın hatalı olduğunu varsayar. Kant açısından anlayışımızın bir kısıtlılığı olarak görülmesi gereken durum hatalı biçimde dizinin olanaksızlığı olarak görülür. ${ }^{112}$ Öznel koşulun nesnel sayılması yanılsamaya yol açar.

Kant'a göre tözsel bir bileşik varsa bileşim yasaları da vardır. Bir bileşimde parçaların oluşumunda sonsuz bir gerileme bulunmaz. Başka deyişle herhangi bir bileşik belirli sayıda parçadan oluşur. Dünyanın büyüklüğü sınırlıdır. Evren kütlesi bağlamında matematiksel anlamda sonludur. Evrenin geçmiş süreci ölçülerek verilebilir. Bütün bu yargılar duyusal bilgi bağlamında ortaya konur. Yukarıda, dünya bölümünde vurguladığımız üzere Kant’ın söz konusu görüşleri eleştirel dönemin matematiksel antinomileri ile bağlantılıdır ancak Kant henüz antinomi düşüncesinden uzaktır. Buradaki yönelimi nicelik kavramının ele alınışının duyusallık ve anlayı̧ açısından ayrı biçimde düşünülmesine ilişkindir. 
Kant'ın ikinci yanıltıcı aksiyom türünün ikincisi çelişmezlik ilkesinin hatalı çevrilmesinden kaynaklanır. Burada zaman öyle kullanılır ki aynı şeye ilişkin aynı anda çelişik iki yüklem yer alır: Böylece "her ne, eş zamanlı ve eş zamanlı değilse, olanaksızdır" ortaya konur. Burada duyusal yasalarla uyumlu verilen bir şey anlayış aracılığıyla yüklemlenerek bütünüyle doğru ve apaçık bir yargı elde edilir. ${ }^{13}$ Öte yandan bu yargının dönüştürülmesiyle ortaya konan "olanaksız her şey eş zamanlıdır ve eş zamanlı değildir” yargııı bir çelişki içerir. Burada duyusal bilgi aracılı̆̆ıyla aklın bir nesnesi hakkında bir şey genel olarak yüklemlenir. Yargı bu biçimiyle, insan anlayışının sınırları ve kısıtlamaları bağlamında doğrudur. Ne var ki, nesnel ve genel olarak benimsenemez. Bunun nedeni, anlayış kavramının duyusal bilgi koşullarına konu edilmesidir. Burada sorun böyle bir dönüştürme sonucu elde edilen yargının yalnızca öznel olarak geçerli olmasıdır.

Üçüncü yanıltıcı aksiyom türü özneye özgü koşullardan kaynaklanır. Sorun bu koşulların dikkatsizce nesnelere yüklenmesidir. Duyusal verilen aracılığıyla anlayı̧ın kavramı deneyimdeki bir duruma uygulanır. Bir nesneyi anlayış kavramı altına almanın duyusal koşulunun bulunması yanıltmanın temelinde yer alır. Kant örnek olarak şu yargıyı verir: "Her ne olumsal varolursa bir zamanlar varolmamışırı" ${ }^{114}$. Bu yargı yanlış olmamakla birlikte ancak öznel olarak doğru sayılması gereken bir yargıdır çünkü yalnızca olumsallığın yeterli bir koşulunu ve olumsallığın duyusal belirlenimi için zorunlu bir koşulu dile getirir. Kant’a göre bu yargı anlayı̧̧ yoksunluğu ile ilgilidir. Anlayıs olumsallık ya da zorunluluğun sözde belirleyici özelliklerini açıkça görür fakat real özelliklerini pek seyrek görür. Dolayısıyla, bir tözün karşıtının olanaklı olup olmadı̆̆ı, ancak tözün bir zamanlar var olmadığı saptanırsa bilinecektir, çünkü o, a priori elde edilen belirleyici özelliklerle güçlükle öğrenilebilir. Olumsallığın değişebilirliğe tanıklığındansa, değişim olumsallığın daha güvenilir tanıklığıdır öyle ki, dünyada akan ya da geçici hiçbir şeyle karşılaşılmazsa, olumsallığın ortaya çıkması zor olacaktır. Buna göre "her ne bir zamanda var olmamışsa, olumsaldır” doğru olmasına karşın bu önermenin tersi, bir şeyin zorunlu olarak mı yoksa olumsal olarak mı var olduğunu belirlememizin olanaklı olduğu koşulları belirtir. Buradan Kant öznel bir yasa olarak şunun çıktığını bildirir: "belirli bir şeyin var olmadığı bir zamanın olmuş olduğu saptanmazsa, olumsallığının yeterli belirleyici özelliği, ortak bir anlayış kavramı aracılığıyla verilmez." $115 \mathrm{Bu}$ öznel yasa ise sanki bu ekleme olmadan hiçbir olumsallık olmayacakmışçasına nesnel bir koşula dönüştürülür. İşte bu nokta Kant açısından yanıltmanın kaynağıdır. Söz konusu yasa yalnızca öznel olarak geçerlidir çünkü olumsal varoluşun zorunlu koşulunu dile getirmez. Bunun nedeni ise tüm zaman boyunca var olan olumsal bir şeyin düşünülmesinde çelişki bulunmamasıdır. Kant’a göre bu dünya olumsal var olsa bile o sonsuzdur, süreklidir eş deyişle zamanın her anı ile eş zamanlıdır bu nedenle onun olmadığı bir zaman olduğunu ileri sürmek yanlıştır.

Kant bölümü ve 1770 tezini Saf Aklın Eleştirisi'nin transendental diyalektik bölümünü önceleyen bir tartışma ile bitirir. Burada Kant melez konumda olduğunu varsaydığı bir dizi ilke sunar. Bu yeni ilkeler bir yandan önceki yanıltıcı ilkelerden, duyusal hiçbir sızıntı olmadan 
bütünüyle anlayıştan kaynaklanıyor olmaları bakımından ayrılır. Öte yandan önceki yanıltıcı ilkeler gibi görünüşte bir nesnellik taşırlar. Kant’a göre bu yeni yanıltıcı yargıların kaynağında anlayışın yargılarda kullanılmasının kaçınılmazlığı yatmaktadır. ${ }^{116}$

Kant bu yeni yanıltıcı türde yargıları uyum ilkeleri [Lt. principia covenientiae] olarak adlandırır. Kant bu ilkelerin bırakıldığı durumda anlayışın belirli bir nesne hakkında neredeyse hiçbir yargıya varamayacağını öne sürerek üç örnek verir: (1) "evrende her şey doğanın düzeniyle uyumlu gerçekleşir” (2) "ilkeler mutlak zorunlu olanın ötesinde çoğaltılmamalıdır” (3) "Maddi hiçbir şey var olmaz ya da yok olmaz". ${ }^{117}$

Sessiz on yıldan sonra bu ilkeler Saf Aklın Eleştirisi’nde aklın düzenleyici işlevi ile ilişkilendirilecektir. Böylece anlama yetisinin doğayı deneyimlerin bir birliği olarak kurması olanaklı olacaktır.

\section{1770 Sonrası}

Kant'ın öğrencisi Marcus Herz 1770 tezinin kopyalarını Berlin'deki filozoflar Johann Heinrich Lambert, Johann Georg Sulzer (1720-1779), Moses Mendelssohn’a sunar. Çalışmamızın bu bölümde Kant'ın anılan filozoflar ile mektuplaşmaları sonucu 1770'teki görüşlerinin nasıl değiştiğini konu edeceğiz.

Kant, Lambert'e 2 Eylül 1770'te tezden kısa bir süre sonra yazdığı mektubunda çabasının metafiziği, doğasını ve değişmez yasalarını ortaya koymak için olduğunu yazar. ${ }^{118}$ Devamında ise bir yıldan beri çok farklı bir felsefi konumda olduğunu ve artık her türden metafiziksel sorunun, tümüyle kesin belirli ve basit bir ölçüt uyarınca sorgulanarak çözülebilir olup olmadığının tamlıkla saptanabileceğini bildirir. Öyle ki, içinde hiçbir deneyimden gelen ilkenin yer almadığı saf ahlak felsefesi hakkındaki araştırmalarını kışın bitirmek istediğini ekler. ${ }^{119}$ Kant daha sonra 1770 tezine ilişkin yukarıda andığımız değerlendirmesini yaparak 2., 3. ve 5. bölümlerin dikkate değer olduğunu iletir. Metafiziğe ilişkin açılamasında ise saf, olumsuz bir bilim olarak genel fenomenolojinin metafizik için gerekli oluşuna değinir. Metafizikte duyarlılığın ilkeleri, geçerlilikleri ve sınırlamaları saptanmalıdır. Bu yolla söz konusu ilkelerin saf aklın nesnelerine uygulanması engellenmelidir. Kant henüz bir görüş değişikliği içinde değildir. 1770 tezinin temel varsayımı sürdürülür. Üstelik görüşleri konusunda son derece kendinden emindir.

Herz’in Kant'a yazdığı 11 Eylül 1770 tarihli mektupta Herz, Mendelssohn'la buluşup 1770 tezi hakkında çalıştıklarını bildirir. ${ }^{120}$ Herz, Mendelssohn'un bir Baumgarten izleyicisi olduğunun alına çizerek, pek çok bakımdan teze katılmadığını yazar. Tezin daha geniş yazılmış olmasını dilediğini iletir. Yüklemi duyusal olan yargının öznel geçerli, anlayış kavramı olanın ise nesnel geçerli olduğu konusunda Kant’ın görüşlerine hayran kaldığını ekler. 
Lambert'in 13 Ekim 1770 tarihli mektubu 1770 tezine yönelik ilk önemli eleştirinin yapıldığ1 çalışmadır. Lambert 1770 tezini metafizik ve etiğin nasıl geliştirilebileceğine ilişkin bir kanıtlama olarak gördüğünü belirterek değerlendirmesine başlar. ${ }^{121}$ Daha sonra anladığ biçimiyle tezin bir özetini verir ${ }^{122}$ :

İlk ana sav, insan bilgisinin, bilgi olması ve kendi biçimini taşıması nedeniyle, eski phaenomenon ve noumenon ayrımına göre bölündüğü ve buna bağlı olarak, birbirinden bütünüyle farklı ve deyim yerindeyse heterojen olan iki kaynaktan doğduğudur. Öyle ki bir kaynaktan gelen hiçbir zaman diğerinden türetilemez. Anlayıştan gelen bilginin anlayışa özgü kalması gibi, duyulardan gelen bilgi de duyusaldır ve öyle kalır.

Kant'a sadık bu betimlemenin ardından Lambert ilk eleştirisini paylaşır: İki bilme tarzı ne ölçüde bir araya gelmeyecek kadar ayrıdır? Bu a priori gösterilecekse, duyular ve anlayışın doğasından türetilmelidir. Ne var ki, bunlarla a posteriori karşılaştığımız için ayrım yetilerin nesnelerinin sınıflandırılmasına ve sayılmasına dayandırılmalıdır. Lambert, önünde sonunda kuramın fenomenlere uygulanmak zorunda olduğunu vurgulayarak görünüşlerden ödünç alınmış kavramların ontolojide kullanımının yararlı olduğunu Kant'ın dikkatine sunar. ${ }^{123}$ Görüldüğü üzere Lambert, duyulur ile anlaşılır dünyanın birliğinin kaçınılmazlığını vurgulamaktadır.

Hemen ardından Lambert, astronomun fenomenlerden edindiklerinden yola çıkarak oluşturduğu kuramını yeniden fenomenlere uygulamasını örnek göstererek Kant’a astronom tutumu takınmasını öğütler: "Görünüşs sorununun çok önemli olduğu metafizikte, astronomun yöntemi kesinlikle en güvenli yöntem olacaktır” ${ }^{124}$. Anlaşılacağı üzere Lambert, felsefede Kopernikus devrimini gerçekleştirmeden önce Kant’a devrimin yolunu göstermektedir. Dahası Lambert, "metafizikçinin her şeyi görünüş olarak alabileceğini, boş görünüşü real görünüşten ayırt edebilir ve real görünüşten sonuçlar elde edebilir" ${ }^{125}$ olduğunu bildirmektedir.

Lambert, Kant'in tezin 3. bölümünde bunu yapar göründüğünü belirterek, uzay ve konumu içeren doğrulukların, ebedi ve değişmez doğruluklardan ayrılması konusunda Kant’a hak verir. Öte yandan geometrinin doğrulukları zamanı ve konumu ilineksel olarak değil, özsel olarak içerdiğinden bu doğrulukların ebedi ve değişmez olması gerektiğini öne sürer. Zamanla ilgili büyük oranda Kant’a katıldığı değinilerinden sonra Lambert, Kant’a uzay ve zaman içeren doğrulukların temelini ve kökenini daha derinlemesine göstermenin bir yolunu bulmasını önerir. $\mathrm{Bu}$ öneri de sentetik a priori yargıların temelleri için bir kıvılcım olarak düşünülebilir.

Lambert, Kant'ın yanıltıcı yargı örneklerini konu ederek buralarla ilgili önerilerde bulunur. Buna göre değişimler ve dolayısıyla zaman ve süre real ise 5. bölümde önerilen tümce başka türlü 
ve daha dar olmalıdır. Örneğin Lambert'e göre 27. paragrafta yer alan "her ne varolursa, bir yerde ve bir zamanda var olur" tümcesi bir zamana ve konuma yerleşme anlamına geliyorsa kısmen belirsiz ve hatalıdır çünkü süresi [Alm. Dauer, İng. duration] mutlak olan zamanda değildir. ${ }^{126}$ Daha sonra Lambert, uzay ve zamanın duyulurun yanı sıra anlaşılır dünyada da karşılığı bulunduğunu bildirerek bir kez daha Kant'a duyulur ile anlaşılır olan arasında bağı ele almasını önerir. Kant, 16 Kasım 1781 tarihinde Bernoulli'ye yazdığı mektupta Lambert'in bu mektubunu anımsatarak "o [Lambert] muhteşem insan uzay ve zaman hakkında dile getirdiğim görüşlerime karşı çıktı, ben de ona Saf Aklın Eleştirisi'nde cevap verdim”" ${ }^{127}$ demektedir. Dolayısıyla Lambert, Kant'ın da andığı üzere 1770 tezinin eleştirel felsefeye evrilmesinin kurucu kişilerinden biridir.

Johann Georg Sulzer 8 Aralık 1770 tarihinde Kant'a felsefeye yeni bir canlılık kattığını yazar. ${ }^{128}$ Her bir kavramı tam olarak geliştirmeyi ve uygulanışını açık olarak göstermeyi önerir. Uzay ve zaman konusunda Leibniz’e katıldığını zamanın süreden, uzayın yayılımdan farklı olduğunu bildirir.

25 Aralık 1770 tarihinde Mendelssohn, Kant'a yazdığı mektupta tezin uzun bir düşünüş sürecinin ürünü olduğunun görülebileceğini ve bütün bir dizgenin parçası olarak görülebileceğini yazar. ${ }^{129}$ Buna karşın belli bölümleri anlaşılması güç bulduğunu dile getirir. Mendelssohn, yayılımsal büyüklükte sonsuzluğa ilişkin ve Shaftesbury ile Epikuros arasındaki bağa ilişkin iki değininin ardından, zamansal ardışıklık tartışmasına girer. Mendelssohn’a göre zaman yalnızca özneldir. Onun açısından ardışıklık sonlu zihinlerin taşıdığı tasarımların zorunlu bir koşuludur. Ancak sonlu zihinler yalnızca özne değildir; onlar aynı zamanda hem Tanrı'nın hem de akranlarının tasarımlarının nesneleridir. Buradan Mendelssohn’un ulaşıı̆g sonuç ardışıklığın nesnel bir şey olarak görülmesi zorunluluğudur. ${ }^{130}$ Mendelssohn’un Kant’a bir başka karşı çıkışı 1770 tezinde eş zamanlılığın çelişmezlik ilkesi açısından zorunlu tutuluşunadır. ${ }^{131}$

7 Haziran 1771 tarihinde Kant, Herz'e yazdığı mektupta Lambert ve Mendelssohn'dan gelen değerlendirmeleri önemsediğini ve gerektiğinde daha önce benimsediği görüşleri alaşağ etmeye hazır olduğunu yazar. Yetilerin öznel ilkelerini ve kullanımlarını ayırt etmenin felsefe için ne denli önemli olduğunu bir kez daha vurgular. Daha sonra "Duyusallığın ve Aklın Sınırları" adını verdiği bir çalışmayla uğraştığını belirtir. Çalışmanın içeriğini ise duyusal dünyayı belirleyen kurucu yasaları ve ilkeleri ayrıntılı biçimde anlatmak bunun yanı sıra beğeni, metafizik ve ahlak felsefesi açısından kaçınılmaz olanlara ilişkin bir taslak oluşturmak olarak duyurur. Kışın bu konudaki tüm ilgili içeriği ölçüp, biçip, düşünerek sonunda işi kotarmanın uyumlu bir yolunu bulduğunu açıklar. Mektubunu tamamlarken yayıncı Herr Kanter'in 1770 tezini oldukça geç ve az sayıda ve hatta Leipzig Kitap Fuarı Kataloğunda listelemeden gönderdiğini yazar. Çalışmaya ilişkin kimi değişikleri çoktan yaptığını dahası bir daha sunmak istemeyeceği görüşler barındırdığından

131 William J. Eckoff, Kant's Inaugural Dissertation of 1770 (New York: Columbia College, 1894) 87. 
tezi yeniden basmaya değer görmediğini bildirir. ${ }^{132}$ Bu mektuptan Kant' in 1770 tezindeki kimi görüşleri değiştirdiğini anlıyoruz. Değişen görüşlerini yazmadığından bunların Lambert'in daha önce dile getirdiği eleştirilerle ilgisini bu aşamada kuramıoruz. Bunun için bir yıl sonra Herz’e yazacağı mektubu bekleyeceğiz.

9 Temmuz 1771'de Herz, Kant'a yazar. Herz, bir başkasından, Herr Friedländer'dan, Kant'in eskisi kadar kurgusal felsefeye adanmış olmadığını duyduğunu, metafiziği anlamsız ve kafa karıştırıcı gördüğünü aktarır. Ardından Kant'tan aldığı mektupla rahatladığını ekler. Kant'ın hala metafiziğe kendini adamış olmasından sevinç duyduğunu bildirir. Daha sonra kendi yazdığ Spekülatif Dünya Bilgeliği Hakkında İncelemeler'de Kant'tan esinlenişini anlatarak mektubunu tamamlar.

21 Şubat 1772'de Kant, Herz'e ünlü mektubu kaleme alır. Bu mektup Saf Aklın Eleştirisi’nin doğumunu muştulayan "the Herz letter” olarak anılır. Kant, Herz’le tartıştıkları bir çalışmayı anarak onu felsefenin tamamına ve bilginin geri kalanına uyarlamak, kapsamını ve sınırlarını anlamak için bir kez daha incelediğini açıklar. ${ }^{133}$ Daha önce duyusal olanı anlayıştan ahlak alanında ayırdığını anımsatır. Önceleri tasarladığı Duyusallığın ve Aklın Sınırları adlı kitap taslağını konu ederek bu çalışmanın teorik ve pratik olmak üzere iki bölümden oluşmasını uslamladığını belirtir. Teorik bölüm genel fenomenoloji ile doğası ve yöntemi bakımından metafizik olmak üzere iki kesimden oluşur. Pratik bölüm ise duyusal istek, beğeni ve duygunun evrensel ilkeleri ile ahlakın ilk ilkeleri olmak üzere iki kesimden oluşur. Daha sonra teorik bölüm hakkında düşündükçe bir temel konunun göz ardı edildiğini fark ettiğini yazar. Bu konu şimdiye kadar kendisinin ve başkalarının metafiziği düşünürken gözden kaçırdıkları bir konudur. Kant şöyle demektedir ${ }^{134}$ :

Bizde bulunan tasarım [Alm. Vosrstellung] dediğimiz şeyin nesneyle bağıntısının temeli nedir? Bir tasarım, yalnızca öznenin nesneden etkilenme tarzını [Alm. Art] içeriyorsa, bu durumda bu nesneyle nasıl uyumlu olduğunu görmek kolaydır. Öyle ki, bir etki nedeni ile uyuşur ve zihnin [Alm Gemüths] bu belirlenimi [Alm. Bestimmung] ile bir şey tasarlayabildiği kolaylıkla görülür. Böylece edilgin ya da duyusal tasarımlar, nesnelerle anlaşılabilir bir bağıntı içindedir. Ruhumuzun [Alm. Seele] doğasından türetilen ilkeler, bu duyuların nesneleri olduğu sürece tüm şeyler için kavranılabilir [Alm. begreifliche] bir geçerlilik taşır. Aynı biçimde, içimizde "tasarım" dediğimiz şey nesne bağlamında etkin olsaydı, başka deyişle nesnenin kendisi tasarım yoluyla oluşturulsaydı tıpkı tanrısal bilgilerin şeylerin asılları [Alm. Urbilder] olarak tasarlanması gibi, bu tasarımların nesnelerine uygunlukları da anlaşılabilirdi. Bu nedenle, bir intellectus archetypi, [eş deyişle] görüsü şeylerin temelinin kendisi olan bir anlayış, bir intellectus ectypus [eş deyişle] olanağı, şeylerin duyusal görüsünden mantıksal yordamı için veri türeten bir anlayış, en azından anlaşılabilir. Bununla birlikte, anlayışımız tasarımlar aracılığıyla, ne 
nesnenin nedeni (iyi ereklerin ahlakı dışında) ne de anlayış-tasarımlarının [Alm. Verstandesvorstellungen] nedeni olan nesnesidir (sensu reali [gerçek anlamda]). $\mathrm{Bu}$ nedenle anlayışın saf kavramları duyuların duyumlarından soyutlanmamalı ve tasarımların alıcılığını duyular aracılı̆̆ıyla dile getirmemelidir; ama gerçekten de kaynakları ruhun [Alm. Seele] doğasındadır, bunlar ne nesneden kaynaklanır ne de nesnenin kendisini meydana getirir. 1770 tezinde yalnızca olumsuz bir yaklaşımla anlayışa ilişkin tasarımların doğasını açıklamaya çalışıı öyle ki, nesne aracılığıyla ruhtaki [Lat. Seele] değişimler olarak görmeyerek. Fakat, bir nesneyi imleyen bir tasarımın ondan belli bir tarzda etkilenmeden nasıl olanaklı olabileceği sorusunu sessizce atladım. Demiştim ki, duyusal tasarımlar şeyleri göründükleri gibi, anlayışa dayalı tasarımlar ise oldukları gibi tasarlar. Fakat bu şeyler etkileme tarzlarıyla değilse, bize hangi yollarla veriliyor? Bu tür anlayışa dayalı tasarımlar içsel etkinliğimize dayanıyorsa, yine de böylesi üretilemeyen nesnelerle aralarında olduğu varsayılan uyuşma nereden geliyor? Ve saf aklın bu nesnelere ilişkin aksiyomları, bu nesnelerle nasıl uyuşuyor üstelik bu uyuşma deneyim yardımıyla sağlanmadan?

Kant, bu aşamada artık 1770 tezi bağlamında anlayışın nesnelerin niteliklerini bildiren kavramların olanağını real ilkelerle açıklayamayacağı görüşündedir. Bu ilkelerin bir yandan deneyimle uyuşması, bir yandan deneyimden bağımsız olması beklenmektedir. Oysa 1770 tezi bağlamında anlayışın şeylerin kendileriyle uyuşması belirsizdir. ${ }^{135}$

Kant mektubunun ilerleyen bölümlerinde eleştirel dönem açısından kurucu bir kavramı ilk kez kullanır: transendental felsefe. Bilgi arayışını konu ederek, onsuz, metafiziğin sınırlarını ve doğasını belirleyemeyeceğimizi belirtir. Daha sonra metafiziği özsel olarak bölümlediğini ekleyerek "transendental felsefeyi, eş deyişle saf aklın tüm kavramlarını belirli sayıda kategoriye indirgemeyi” 136 araştırdığını ekler. Kategorileri, anlayısıı az sayıda temel yasasını izleyerek düzenlediğini bildirir. Devamında araştırmalarında başarılar elde ettiğini artık "kuramsal olduğu kadar -salt anlayışa dayalı-pratik bilginin doğası hakkında saf aklın eleştirisini [italik benim] yapabilecek konumda” olduğunu ekler ${ }^{137}$. Yazmayı düşündüğü Duyusalliğın ve Aklın Sınırları eserinin ilk bölümünde metafiziğin kaynakları, yöntemi ve sınırları üstünde duracağını ve üç ay içinde yayınlamayı öngördüğünü yazar. Ne var ki bu çalışması on yılını alacaktır ve ancak 1781 yılında Saf Aklın Eleştirisi Kant'ın bu mektupta sözünü ettiği içeriği elde edebilecektir.

Daha sonra Kant, Königsberg'teki en parlak zihinlerden biri olarak nitelediği Papaz Schultz'un 1770 tezi yorumlarını değerlendirir. Schultz'un, Kant'ın kendi uzay anlayışına yönelik, duyusal görünüşlerin saf formu olmasındansa anlayışa dayalı görü ve dolayısıyla nesnel olabileceğine ilişkin yorumunu aktarır. Kant ise yanıtında uzayın nesnel ve anlayışa dayalı olmayışının gerekçesini uzay tasarımının çözümlenişinde ne şeyler ne de onlar arasında real 
bağıntılar bulunduğunu vurgular. ${ }^{138}$ Kant, Schultz’un öteki eleştirisini ise önemsediğinin altını çizer. Buna göre değişimler içsel duyumun tanıklığında gerçektir. Şu durumda zaman önden varsayılırsa değişimler olanaklıdır. Dolayısıyla zaman nesnel ve gerçektir öyle ki, kendinde şeylerin belirlenimlerinde içerilir. Kant ise dışsal şeyler bağlamında tasarımların gerçekliğinden nesnenin gerçekliğini çıkamayacağını vurgular. Fakat içsel duyum durumunda düşünüş ya da düşüncenin varlığı ve kendi benimizin bir ve aynı olduğunun altını çizer. Değişimlerin edimselliği [Alm. wirklich] olduğunu cisimlerin edimselliği olduğundan daha çok yadsımayacağını ekleyerek tüm demek istediğinin görünüşlere edimsel bir şeyin karşılık geldiği olduğunu belirtir.

\section{Sonuç}

1770 tezi, çalışmamızda ayrıntılı biçimde ortaya koyduğumuz üzere birbirinden farklı ilkeleri olan duyulur dünya ile anlaşılır dünya ayrımı temelinde kaleme alınmıştır. Bu çerçevede Kant’ın metafiziği tartışmalı yanlarından arındırıp güvence altına alabilmeye yönelik çözümünün anlaşılabilir olanı duyusallığın alanından "korumak" olduğunu da gördük. İşte tam bu noktada Kant’ın çözümü onun düğümüne dönüşür. Kant bir yandan, anlaşılabilir dünyada tözlerin karşılıklı etkileşiminden söz etmek durumundayken öbür yandan etkileşimi olanaklı kılan uzay ve zamana anlaşılabilir dünyada yer vermez. Öte yandan çalışmasının 4. bölümünün başında Kant, anlaşılır dünyanın formunun ilkeleri yoluyla tözlerin karşılıklı etkileşiminin kavranabileceğini belirtir. Öyleyse anlaşılır dünyadaki şeyler birbirleriyle etkileşmektedir. Etkileşim ise tözlerin durumlarında değişikliğe yol açar. Değişikliğin ortaya çıkabilmesi için sürekliliğin, sürekliğin olabilmesi içinse zamanın olması gerekir. Oysa Kant’a göre uzay ve zaman duyusallığın koşuludur. Duyusal olmayan tözler duyusallığın konusu olamaz. Bu durumda anlaşılır dünya içinde herhangi bir değişikliğin olmaması gerekir. Ne var ki, Kant çalışmamızın ikinci bölümünde ortaya koyduğumuz üzere tözler arasındaki etkileşimin gerçek olduğunu söylediğini göre, burada bir çelişki söz konusudur.

Kant'ın metafiziğe yönelik eleştirel dönemde süren ilgisi, 1770 tezinin 4 . bölümünde ortaya konan anlaşılır dünyaya ilişkin savların tam tersi biçimde evrilir. Eleştirel felsefe böylesi bir metafiziğin olanaksızlığı üzerine kuruludur. Bununla birlikte duyulur dünyayı anlama biçimi eleştirel dönemde büyük oranda korunur.

Üçüncü bölümde serimlediğimiz gibi Kant açısından anlayıs, kavramlarını kendi doğasında aramalıdır. Üstelik doğuştan kavramlar [Lt. conceptus connati] olarak değil zihnin [Lt. menti] içkin yasalarından, deneyim sırasındaki edimlerinden elde edilmiş kavramlar olarak. Kant burada zihnin kendi işlemleri üstüne düşünerek taşıdığı olanakları deneyim dolayımıyla fark ettiğini vurgulamaktadır. Buna karşın söz konusu yaklaşım önemli bir başka soruna yol açar. Yukarıda değindiğimiz üzere, real kullanımında anlayıs hiçbir duyusallık taşımamaktadır. Oysa şimdi Kant deneyimdeki edimleri üzerinden anlayıs kavramları ile deneyim arasında bağ kurmaktadır. Şu durumda Kant anlaşılır dünya içinde hiçbir duyusallık bulunmadığını varsayarken anlayı̧ kavramlarının, deneyim yoluyla uzay zaman koşullarında bilgisini edindiğimiz dünyaya nasıl

$13810: 133$. 
uygulanabileceğini gözden kaçırır. Kendi deyişiyle: "Fakat, bir nesneyi imleyen bir tasarımın ondan belli bir tarzda etkilenmeden nasıl olanaklı olabileceği sorusunu sessizce atladım”. Çalışmasında böylesi bir sorun olduğunun farkına varışı ise Herz’e gönderdiği mektuptan anlaşılacağı üzere 1772'de olmuştur. Duyusal tasarımlar ile anlayışa dayalı tasarımların ayrı tutulması nesneyi oluşturabilme olanağını zedelemektedir.

1770 tezindeki duyulur olan ile anlaşılır olan ayrımını eleştiren Lambert, saf kavramların nesnelere uygulanması açısından deneysel bilginin zorunlu olduğunu dile getirerek ontolojinin fenomenlere uygulanmasını Kant'ın dikkatine sunar. Lambert'in söz konusu uyarısına karşın 1772'ye kadar Kant'ın bunu göz ardı ettiğini varsayabiliriz. 1772 Herz mektubunda "bizde bulunan tasarım dediğimiz şeyin nesneyle bağıntısının temeli nedir?” sorusunun peşine düşmesiyle birlikte Kant’ın eleştirel döneme girdiğini söylemek yanlış olmayacaktır. Öyleyse "mağrur ontolojiden alçakgönüllü saf anlama yetisi kavramlarının analitiğine" 139 geçişi Lambert'le başlamıştır. Böylelikle Kant gerek Lambert'in deneyimden kaynaklanmayan kavramların deneyime nasıl uygulanabileceği, gerekse de Hume’un deneyim düzeyinde iki kavram arasında nasıl zorunlu bağlantı olabileceğine ilişkin sorunlarını aşar.

1770 tezindeki bir öteki sorun Kant'ın töz kavrayışına ilişkindir. Kant tözlerin ve tözler arasındaki etkileşimin anlayış aracılığıyla bilinebileceğini savlar. Tözler arasındaki etkileşim değişime karşılık gelir. Değişim ise zamansallık gerektirir. Zamansallık duyulur dünyanın ilkesidir. Oysa tezin önemli varsayımlarından biri duyulur dünyanın ilkesinin anlaşılır dünyanın ilkesi olamayacağıdır. Lambert'in 13 Ekim 1770 mektubunda da dikkat çektiği bu konu Kant'ın tezdeki tartışmalarının kapatılamaz gediğidir.

Bir diğer nokta Kant’ın duyarlığı nesnelere yönelik alırlığı olan bir yeti olarak ortaya koymasıyla ilgilidir. Anlayıs gücü ve duyarlık birbirinden kesin olarak ayrılmış iki yeti olduğuna göre, anlayışın nesnelerce etkilenmemesi gerekir. Bu bakımdan anlayışta nesnelerin verilmesine aracılık eden alırlık olamaz. Şu durumda Kant’ın nasıl "anlayış gücünün nesneleri” diyebildiği belirsiz görünmektedir.

Öteki bir sorun, bedenler duyulur dünyaya, ruhlar ise anlaşılır dünyaya ilişkin olduklarından, bedenler ile ruhlar arasındaki etkileşime yönelik sorundur. Böyle bir etkileşimin olanağı ve gerçekleşmesi Kant’’n ayrılmış dünyaları bağlamında kavranılamazdır.

Görüldüğü üzere Herz, Lambert, Mendelssohn ve Schulz’un karşı çıkış ve eleştirileri Kant'ın 1770 tezini yeniden düşünmesine yol açmıştır. Bu yüzden 1771 Haziran'ında Lambert ve Mendelssohn'un mektuplarıyla ilgili olarak Herz’e yazarken, bu iki kişi yüzünden "uzun bir soruşturmalar dizisine takılıp kaldığını” belirtir. Buna karşın Duyarlı̆̆ın ve Aklın Sınırları çalışmasını tamamlayarak üç ay içinde bu sorunları çözebileceğini umar. Ne var ki, kalkıştığı iş öngördüğünden daha büyüktür. Duyarlığın ve Aklın Sınırları bırakın üç ay içinde yazılmayı hiç yazılamaz. 1770 tezi içinde çözümü on yıl sürecek bir sorun olarak duyulur ile anlaşılır dünyanın birlikteliğini taşır. Sorunu çözecek olan Saf Aklın Eleştirisi'dir.

139 A247-B303. 
Hakem Değerlendirmesi: Dış bağımsız.

Çıkar Çatışması: Yazar çıar çatış,ması bildirmemiștir.

Finansal Destek: Yazar bu çalışma için finansal destek almadığını beyan etmiştir.

Peer-review: Externally peer-reviewed.

Conflict of Interest: The author has no conflict of interest to declare.

Grant Support: The author declared that this study has received no financial support.

\section{Kaynaklar / References}

Allison, Henry E. Kant's Transcendental Deduction An Analytical-Historical Commentary. Oxford: Oxford University Press, 2015.

Beck, Lewis White. Essay on Kant and Hume. New Haven: Yale University Press, 1978.

Beiser, Frederick C. "Kant's Intellectual Development: 1746-1781". Içinde The Cambridge Companion to Kant, editör Paul Guyer, 26-61. Cambridge: Cambridge University Press, 1992.

Cassirer, Ernst. Kantin Yaşamı ve Öğretisi. Çeviren Doğan Özlem. İstanbul: İnkılâp Kitabevi, 1996.

Eckoff, William J. Kant's Inangural Dissertation of 1770. New York: Columbia College, 1894.

Gözkân, H. Bülent. Kant’’n Şemsiyesi. İstanbul: YKY, 2018.

Guyer, Paul. Kant. New York: Routledge, 2006.

Kant, Immanuel. "De Mundi Sensibilis atque Intelligibilis Forma et Principiis". Içinde Kant's Gesammelte Schriften Preußische Akademie der Wissenschaften, C. 2, 1926.

—. "Dissertation on the Form and Principles of the Sensible and Intelligible World". Içinde Kant's Inaugural Dissertation and Early Writings on Space, çeviren John Handyside, 35-85. Chicago : London: The Open Court Publishing Company, 1929.

- "Kritik der reinen Vernunft". Içinde Kant's gesammelte Schriften Preußische Akademie der Wissenschaften, C. 3. Berlin: Georg Reimer, 1911.

"On the Form and Principles of the Sensible and the Intelligible World [Inaugural Dissertation]". Içinde Theoretical Philosophy, 1755-1770, çeviren David Walford ve Ralf Meerbote, 373-416. New York: Cambridge University Press, 1992.

—. Philosophical Correspondence 1759-1799. Çeviren Arnulf Zweig. Cambridge: Cambridge University Press, 1999.

" "Prolegomena zu Einer Jeden Künftigen Metaphysik, die als Wissenschaft Wird Auftreten Können". Içinde Kant's gesammelte Schriften Preußische Akademie der Wissenschaften, C. 4. Berlin: Georg Reimer, 1911.

Kuehn, Manfred. Kant: A Biography. Çeviren Bülent O. Doğan. İstanbul: Türkiye İş Bankası Kültür Yayınları, 2011.

Layvine, Alison. "Kant's Early Metaphysics and the Origins of the Critical Philosophy". Içinde North American Kant Society Studies in Philosophy, editör Manfred Kuehn ve Karl Ameriks, C. 3. California: Ridgeview Publishing Company, 1993.

Risi, Vincenzo De. "Analysis Situs, the Foundations of Mathematics, and a Geometry of Space". Içinde The Oxford Handbook of Leibniz, editör Maria Rosa Antognazza, 247-58. New York: Oxford university press., 2018.

Russell, Bertrand. The Philosophy of Leibniz. London: Routledge, 1997.

Santos, Paulo R. Licht. "The Real Use of the Understanding and Ontology in Kant's Inaugural Dissertation". Içinde Kant Und Die Philosophie in Weltbürgerlicher Absicht: Akten des Xi. Kant-Kongresses 2010, editör Margit Ruffing, Claudio La Rocca, Alfredo Ferrarin, ve Stefano Bacin, 647-58. De Gruyter, 2010.

Schönfeld, Martin, ve Michael Thompson. "Kant's Philosophical Development". Içinde The Stanford Encyclopedia of Philosophy, editör Edward N. Zalta, 2019.

Ward, James. A Study of Kant. Cambridge: Cambridge University Press, 1922. 
